\title{
Bioinformatics-Enabled Identification of the HrpL Regulon and Type III Secretion System Effector Proteins of Pseudomonas syringae pv. phaseolicola 1448A
}

\author{
Monica Vencato, ${ }^{1}$ Fang Tian, ${ }^{2}$ James R. Alfano, ${ }^{2}$ C. Robin Buell, ${ }^{3}$ Samuel Cartinhour, ${ }^{4}$ \\ Genevieve A. DeClerck, ${ }^{4}$ David S. Guttman, ${ }^{5}$ John Stavrinides, ${ }^{5}$ Vinita Joardar, ${ }^{3}$ Magdalen Lindeberg, ${ }^{1}$ \\ Philip A. Bronstein, ${ }^{4}$ John W. Mansfield, ${ }^{6}$ Christopher R. Myers, ${ }^{7}$ Alan Collmer, ${ }^{1}$ and \\ David J. Schneider ${ }^{4}$ \\ ${ }^{1}$ Department of Plant Pathology, Cornell University, Ithaca, NY 14853, U.S.A.; ${ }^{2}$ The Plant Science Initiative and the \\ Department of Plant Pathology, University of Nebraska-Lincoln, 68588, U.S.A.; ${ }^{3}$ The Institute for Genomic Research, \\ 9712 Medical Center Dr., Rockville, MD 20850, U.S.A.; ${ }^{4}$ United States Department of Agriculture-Agricultural Research \\ Service, Ithaca, NY 14853, U.S.A.; ${ }^{5}$ Department of Botany, University of Toronto, 25 Willcocks St., Toronto, ON M5S 3B2 \\ Canada; ${ }^{6}$ Agricultural Sciences Department, Imperial College at Wye, Ashford, Kent TN25 5AH, United Kingdom; ${ }^{7}$ Cornell \\ Theory Center, Cornell University, Ithaca, NY 14853, U.S.A.
}

Submitted 25 January 2006. Accepted 14 July 2006.

The ability of Pseudomonas syringae pv. phaseolicola to cause halo blight of bean is dependent on its ability to translocate effector proteins into host cells via the hypersensitive response and pathogenicity (Hrp) type III secretion system (T3SS). To identify genes encoding type III effectors and other potential virulence factors that are regulated by the $\mathrm{HrpL}$ alternative sigma factor, we used a hidden Markov model, weight matrix model, and type III targeting-associated patterns to search the genome of $\boldsymbol{P}$. syringae pv. phaseolicola 1448 A, which recently was sequenced to completion. We identified 44 high-probability putative Hrp promoters upstream of genes encoding the core T3SS machinery, 27 candidate effectors and related T3SS substrates, and 10 factors unrelated to the Hrp system. The expression of 13 of these candidate HrpL regulon genes was analyzed by real-time polymerase chain reaction, and all were found to be upregulated by HrpL. Six of the candidate type III effectors were assayed for T3SSdependent translocation into plant cells using the Bordetella pertussis calmodulin-dependent adenylate cyclase (Cya) translocation reporter, and all were translocated. PSPPH1855 (ApbE-family protein) and PSPPH3759 (alcohol dehydrogenase) have no apparent T3SS-related function; however, they do have homologs in the model strain $P$. syringae pv. tomato DC3000 (PSPTO2105 and PSPTO0834, respectively) that are similarly upregulated by HrpL. Mutations were constructed in the DC3000 homologs and found to reduce bacterial growth in host Arabidopsis leaves. These results establish the utility of the bioinformatic or candidate gene approach to identify-

Corresponding author: David J. Schneider; E-mail: djs30@ cornell.edu

* The $\boldsymbol{e}$-Xtra logo stands for "electronic extra" and indicates the HTML abstract available on-line contains a supplemental table not included in the print edition.

This article is in the public domain and not copyrightable. It may be freely reprinted with customary crediting of the source. The American Phytopathological Society, 2006. ing effectors and other genes relevant to pathogenesis in $P$. syringae genomes.

Additional keywords: Avr/Hop proteins.

The HrpL alternative sigma factor activates the expression of multiple genes that are essential to the plant pathogenicity of Pseudomonas syringae (Willis and Kinscherf 2004). The most important of these are genes encoding the type III secretion system (T3SS) and effector proteins that are injected by the T3SS into host cells. The T3SS is encoded by hypersensitive response and pathogenicity $(h r p)$ and $h r p$ conserved $(h r c)$ genes. Effector proteins are encoded by avirulence (avr) and Hrp outer protein (hop) genes, whose different names reflect the phenotype used to discover them (Lindeberg et al. 2005). $P$. syringae is a host-specific pathogen divided into more than 50 pathovars based largely on host range, and hrp mutants lose the ability to elicit the defense-associated hypersensitive response (HR) in nonhosts or to be pathogenic in hosts (Lindgren et al. 1986).

HrpL is a member of the extracytoplasmic family (ECF) of alternative sigma factors and activates promoters that have the canonical sequence GGAACC- $\mathrm{N}_{16}$-CCACNNA as well as many variants of this sequence (Innes et al. 1993; Shen and Keen 1993; Xiao and Hutcheson 1994). A hidden Markov model (HMM) and weight matrix (WM) analysis was used to identify putative Hrp promoters in the genome of $P$. syringae pv. tomato DC3000 during the draft phase of a now-completed genome project (Buell et al. 2003; Fouts et al. 2002). The set of putative Hrp promoters enabled efficient identification of candidate effector genes based on several additional features, most notably N-terminal amino-acid patterns typical of T3SS substrates (Guttman et al. 2002; PetnickiOcwieja et al. 2002; Schechter et al. 2004). Because virtually all type III effector genes are associated with Hrp promoters and T3SS targeting patterns in DC3000, this bioinformatic approach is predicted to provide an efficient and potentially comprehensive means to identify novel candidates in newly sequenced $P$. syringae strains. 
In addition, our analysis of the DC3000 HrpL regulon revealed several genes whose products are unlikely to have a T3SS-related function (Ferreira et al. 2006; Fouts et al. 2002). These include indoleacetate-lysine ligase, a syringomycin phytotoxin biosynthesis homolog, and a regulator of the biosynthesis of the coronatine phytotoxin. These observations suggest that HrpL coordinates the expression of multiple classes of factors promoting virulence and growth within plants. Comparison of the Hrp promoter inventories of phylogenetically divergent strains of $P$. syringae should reveal which components of the HrpL regulon are conserved and potentially involved in basic interactions with all plants and which components are variable and potentially control host specificity.

$P$. syringae pv. phaseolicola 1448 A recently has been sequenced and is the focus of this study (Joardar et al. 2005). Phylogenetic analyses have revealed that most $P$. syringae pathovars group into three separate clusters, and pvs. tomato and phaseolicola represent two of these (Sarkar and Guttman 2004; Sawada et al. 1999). P. syringae pv. phaseolicola can be a devastating pathogen and is a useful experimental model for several reasons. $P$. syringae pv. phaseolicola strains have been assigned to nine races based on interactions with various bean cultivars, and several type III effector genes have been cloned from these races based on their gain-of-function avirulence phenotypes in tests with bean cultivars carrying different resistance $(R)$ genes (Arnold et al. 2001; Jenner et al. 1991; Puri et al. 1997). Race 6 strains, such as 1448A, are compatible with all differential bean cultivars and, therefore, have been particularly useful for identifying effector genes from other races (Tsiamis et al. 2000). Studies of the P. syringae pv. phaseolicola Hrp system have been seminal. The hrp genes were discovered in $P$. syringae pv. phaseolicola, and experiments with this pathovar provided the first evidence that some effectors can suppress defense responses triggered by other effectors in the same bacterium (Jackson et al. 1999; Lindgren et al. 1986). Recently, quantitative real-time polymerase chain reaction (PCR) was used to determine the expression of each of the promoters expressing the T3SS and four substrates (HrpZ1, HopX1, HopF1, and HopAB1) in P. syringae pv. phaseolicola under inducing conditions in culture and in planta (Thwaites et al. 2004). A key finding was that the HrpL regulon is expressed much more strongly in planta than in culture.

In this report, bioinformatic analysis of the HrpL regulon of P. syringae pv. phaseolicola 1448 A was performed using an HMM that was developed and validated with $P$. syringae pv. tomato DC3000 (Ferreira et al. 2006; Fouts et al. 2002). A preliminary analysis was performed on a draft genome sequence of 1448A, which aided annotation of virulence-related genes in the published genome (Joardar et al. 2005). The analysis was repeated on the completed genome and candidate HrpLregulated genes were experimentally profiled, as reported here. The assays included real-time PCR and T3SS translocation tests involving both the Bordetella pertussis calmodulindependent adenylate cyclase (Cya) and AvrRpt 2 translocation reporters. The results of these experiments enabled us to compare the HrpL regulons and type III effector inventories of 1448A and DC3000. Two genes that are activated by HrpL in both strains but have no apparent T3SS-related function were mutated and tested for virulence in the model $P$. syringae strain DC3000. Importantly, while this work was in preparation, a report of a near-saturating screen for HrpL-responsive promoters and type III effector genes in DC3000 and 1448A was published (Chang et al. 2005). Comparison of the datasets resulting from the genetic screen and the bioinformatic approach confirmed the comprehensiveness of the latter. Furthermore, the bioinformatic approach yielded three more 1448A T3SS substrates that had not been reported before.

\section{RESULTS}

Identification of candidate Hrp promoters in the genome of $P$. syringae pv. phaseolicola 1448A using an HMM trained on $P$. syringae pv. tomato $\mathrm{DC} 3000$.

The HMM analysis reported here was applied to the complete and annotated sequence (Joardar et al. 2005). The bioinformatic methods used are based on the refined HMM2 and WM2 analyses that were developed in conjunction with microarray verification of HrpL-responsive promoters in DC3000 (Ferreira et al. 2006). These methods are summarized in Figure 1. Our analysis revealed 44 candidate hrp promoters with a high likelihood of being active because they had an HMM2 score greater than 10.0, a WM2 score greater than 4.0, and a distance between the promoter and apparent start site of less than $220 \mathrm{bp}$. We exploited the reciprocal best hit BLAST analysis reported by Joardar and associates (2005) to determine whether the DC3000 orthologs of open reading frames (ORFs) in the predicted 1448A HrpL regulon had been shown by microarray analysis to be in the DC3000 HrpL regulon (Ferreira et al. 2006). A subset of these candidates (Table 1) are of particular interest because downstream genes encode Avr/Hops or have HrpL-activated orthologs in P. syringae pv. tomato DC3000. A complete list of candidate hrp promoters, including those with weaker scores, is presented in Supplementary Table 1 along with genome coordinates, operon predictions, and other information. Instructions and files that support viewing of the candidate Hrp promoters in the annotated 1448A genome sequence using Artemis software are available at the Pseudomonas-Plant Interaction website. In total, 31 of the high-probability candidate Hrp promoters in $1448 \mathrm{~A}$ are found on the chromosome and 14 on the larger of the two plasmids.

Homologs of known hop genes were identified by BLAST queries of the 1448A genome with a comprehensive set of known effectors from all $P$. syringae pathovars (Lindeberg et al. 2005). Novel hop gene candidates were identified based on their possession of at least two of the three major T3SS targetingassociated patterns (Schechter et al. 2004,2006) (Fig. 1). For clarity, the hop candidates in Table 1 are given the Hop names that were designated upon experimental confirmation. Table 1 presents four groups of genes: i) avr/hop genes with HrpLactivated DC3000 homologs, ii) avr/hop genes without DC3000 homologs, iii) genes with no apparent role in the T3SS that have a HrpL-activated homolog in DC3000, and iv) genes with promoters that are below the HMM 2 cutoff but above the WM2 cutoff. Within each group, genes are ranked by their HMM2 scores. The differential fluorescence induction (DFI) screen and subsequent translocation tests of Chang and associates (2005) show that a majority of the genes found by our bioinformatic criteria are activated by HrpL and encode Avr/Hop proteins (Table 1). However, the results we present below demonstrate that the bioinformatic approach yields at least one additional member for each of the first three classes presented in Table 1.

\section{Real-time PCR analysis of candidate genes for regulation by the HrpL alternative sigma factor.}

Real-time PCR analysis was used to determine whether 13 Hrp promoters of particular interest were activated by $\mathrm{HrpL}$ and to determine the relative expression of those activated by HrpL (Table 2). The downstream ORFs included genes encoding the T3SS, several Avr/Hop proteins, and proteins with no obvious T3SS-related function. Primers were designed to specifically amplify 100-bp regions in each ORF, and real-time PCR with SYBR Green I technology was used to determine HrpL-dependent expression in either wild-type strains carrying an empty plasmid (pML122) or a plasmid constitutively expressing hrpL (pCPP2308). Analyses were normalized to the 


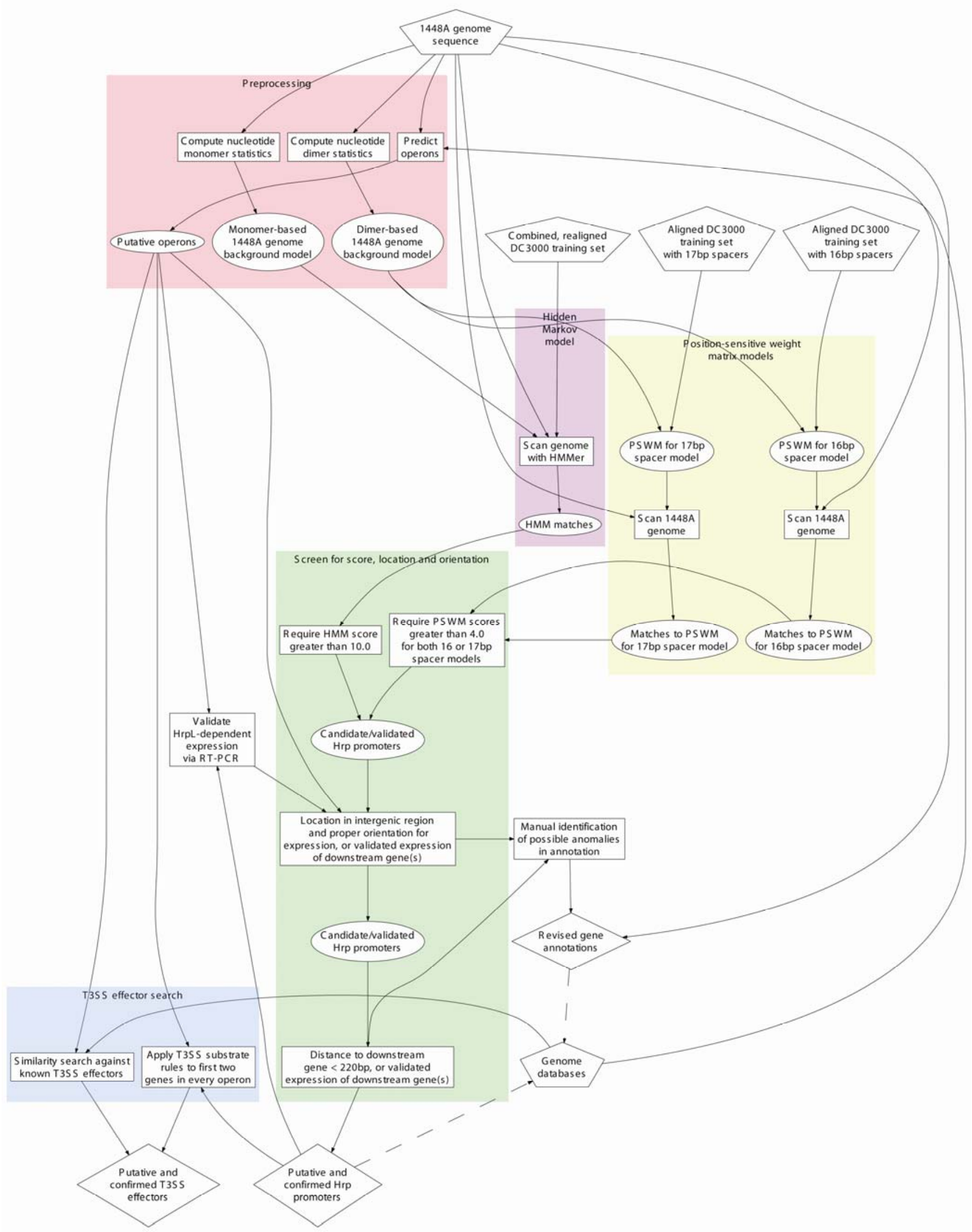

Fig. 1. Bioinformatic workflow represented as a directed graph. The major processing modules are grouped and highlighted by color. The nodes representing primary inputs, primary outputs, processing steps, and intermediate datasets are denoted with pentagons, diamonds, squares, and ellipses, respectively. Feedback pathways that connect primary outputs to primary inputs are indicated by dashed arrows. 
housekeeping gene gyrA (PSPPH3667), which is expressed at a constant level regardless of the $P$. syringae pv. phaseolicola strain and is not regulated by HrpL. This corrected for any inherent differences in the samples, such as initial starting concentration and PCR efficiency.

Four avr/hop genes, PSPPH3028 (avrB4-1), PSPPH4736 (hopAS1), PSPPHA0031 (hopAU1), and PSPPHA0113 $(a v r D 1)$, were shown to be strongly activated by HrpL. Inter- estingly, ORFs PSPPH1855 and PSPPH3759, which encode an ApbE-family protein and a putative alcohol dehydrogenase, respectively, also were activated by HrpL. PSPPH1519 (SlyA/ MarR homolog) and PSPPH1525 (shikimate kinase-like) showed weaker activation, and results varied among biological replicates. Negative controls included PSPPH3960 (putative regulator), PSPPH1381 (putative deoxycytidine triphosphate deaminase), and PSPPH1127 (putative lipoprotein), which are

Table 1. Representative Pseudomonas syringae pv. phaseolicola 1448A genes that are predicted to be in the HrpL regulon by hidden Markov model (HMM) analysis and either encode Hops or have HrpL-activated orthologs in P. syringae pv. tomato DC3000

\begin{tabular}{|c|c|c|c|c|c|c|c|}
\hline \multirow[b]{2}{*}{ Locus $^{b}$} & \multirow[b]{2}{*}{ Name (function) ${ }^{c}$} & \multirow[b]{2}{*}{ HMM2 } & \multirow[b]{2}{*}{$\mathbf{W M}^{\mathbf{d}}$} & \multicolumn{2}{|c|}{ Evidence } & \multicolumn{2}{|c|}{ P. syringae pv. tomato $^{\mathrm{a}}$} \\
\hline & & & & Expression $^{\mathrm{e}}$ & Translocation & Ortholog & Name \\
\hline \multicolumn{8}{|c|}{ avr/hop with DC3000 homolog } \\
\hline A0012-A0011 & hopQ1 & 23.3 & 6.01 & $\mathrm{C}$ & $\mathrm{C}$ & 0877 & hopQ1-1 hopQ1-2 \\
\hline & $\ldots$ & $\ldots$ & $\ldots$ & $\ldots$ & $\ldots$ & 4732 & $\ldots$ \\
\hline 0171 & hopR1 & 20.7 & 6.24 & $\mathrm{C}$ & $\mathrm{C}$ & 0883 & $\ldots$ \\
\hline 1443 & hopAF1 & 20.5 & 6.05 & $\mathrm{C}$ & $\mathrm{C}$ & 1568 & $\ldots$ \\
\hline A0010 & hopD1 & 20.4 & 6.22 & $\mathrm{C}$ & $\mathrm{C}$ & $0876,4724,4726$ & hopD \\
\hline 1263 & hopAA1' (frameshift) & 19.6 & 6.03 & - & & 1372,4718 & һорАА1-1 һорАА1-2 \\
\hline 2351 & hopV1 & 17.6 & 5.37 & $\mathrm{C}$ & $\ldots$ & 4720 & $\ldots$ \\
\hline 1296 & hopX1 & 17.5 & 6.16 & $\mathrm{CR}$ & $\mathrm{C}$ & A0012 & $\ldots$ \\
\hline 1268 & avrE1 & 17.0 & 4.85 & $\mathrm{C}$ & $\ldots$ & 1377 & $\ldots$ \\
\hline 1424 & hорAK1 & 16.6 & 5.08 & $\mathrm{C}$ & $\ldots$ & 4101 & $\ldots$ \\
\hline 3498 & $h o p F 3^{g}$ & 16.2 & 6.06 & $\mathrm{C}$ & $\mathrm{C}$ & 0502 & hopF2 \\
\hline 4736 & hopAS1 & 15.9 & 5.79 & $\mathrm{R}$ & Table 3 & 0474 & hopAS1' \\
\hline \multirow[t]{2}{*}{0763} & hорAJ1 & 15.5 & 6.15 & $\mathrm{C}$ & $\ldots$ & 0852 & $\ldots$ \\
\hline & $\ldots$ & $\ldots$ & $\ldots$ & $\ldots$ & $\ldots$ & 4817 & hорАJ1 \\
\hline 4366 & hopIl & 15.4 & 6.02 & $\mathrm{C}$ & $\mathrm{C}$ & 4776 & $\ldots$ \\
\hline $1265-1266$ & 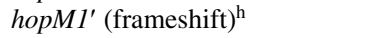 & 14.6 & 4.97 & $\mathrm{C}$ & $\ldots$ & $1374-1375$ & $\ldots$ \\
\hline 1264 & hrpW1 & 13.9 & 6.17 & $\mathrm{C}$ & $\ldots$ & 1373 & $\ldots$ \\
\hline 2294 & hopAB3' (frameshift) & 13.6 & 5.75 & - & - & 3087 & hорAB2 \\
\hline 0767 & hopG1 & 11 & 5.02 & $\mathrm{C}$ & $\mathrm{C}$ & 4727 & $\ldots$ \\
\hline \multicolumn{8}{|c|}{ avr/hop without DC3000 homolog ${ }^{\mathrm{i}}$} \\
\hline A0113 & avrD1 & 23 & 6.8 & $\mathrm{CR}$ & Table 3 & $\ldots$ & $\ldots$ \\
\hline A0122 & hopAW1. & 19 & 5.84 & $\mathrm{C}$ & $\mathrm{C}$ & $\ldots$ & $\ldots$ \\
\hline 3028 & $\operatorname{avrB} 4-1^{\mathrm{j}}$ & 18.8 & 5.47 & $\mathrm{CR}$ & Table 3 & $\ldots$ & $\ldots$ \\
\hline 4326 & hopAE1 & 17.2 & 5.62 & $\mathrm{R}$ & Table 3 & $\ldots$ & $\ldots$ \\
\hline A0120 & $a v r B 2^{\mathrm{k}}$ & 16.1 & 5.75 & $\mathrm{CR}$ & Table 3 & $\ldots$ & $\ldots$ \\
\hline A0031 & hopAU1 & 12.3 & 5.44 & $\mathrm{CR}$ & C, Table 3 & $\ldots$ & $\ldots$ \\
\hline $\mathrm{A} 0075$ & hopW1-2 & 12.1 & 5.02 & $\mathrm{C}$ & $\ldots$ & $\ldots$ & $\ldots$ \\
\hline A0009 & hopW1-1 & 12.1 & 5.02 & $\mathrm{C}$ & $\mathrm{C}$ & $\ldots$ & $\ldots$ \\
\hline A0056 & hopAV1 & 11.6 & 5.26 & - & $\mathrm{C}$ & $\ldots$ & $\ldots$ \\
\hline A0087 & avrRps $4^{\mathrm{l}}$ & 11.4 & 4.74 & $\mathrm{C}$ & $\ldots$ & $\ldots$ & $\ldots$ \\
\hline \multicolumn{8}{|c|}{$\underline{\text { Unrelated to } \mathrm{T} 3 \mathrm{SS}^{\mathrm{m}}}$} \\
\hline 1855 & ApbE-family protein & 22.7 & 6.25 & $\mathrm{R}$ & $\ldots$ & 2105 & $\ldots$ \\
\hline 3759 & alcohol dehydrogenase & & & & & & \\
\hline & (oxidoreductase, zinc-binding) & 0.6 & 6.3 & $\mathrm{CR}$ & $\ldots$ & 0834 & $\ldots$ \\
\hline 1519 & $\begin{array}{l}\text { SlyA/MarR family transcription } \\
\text { regulator }\end{array}$ & 12.5 & 4.68 & $\mathrm{R}$ & $\ldots$ & 1645 & $\ldots$ \\
\hline \multicolumn{8}{|c|}{ Confirmed hop with atypical promoter ${ }^{\mathrm{n}}$} \\
\hline 5225 & hopAT1 & 7.5 & 4.79 & $\mathrm{C}$ & $\mathrm{C}$ & & $\ldots$ \\
\hline A0127 & $h o p A B 1^{\circ}$ & - & 4.84 & - & $\mathrm{C}$ & 3087 & hорAB2 \\
\hline
\end{tabular}

a Orthologs PSPTO number or numbers and name, if different.

${ }^{\mathrm{b}}$ Genes are ranked within categories by the HMM2 scores. PSPPH locus numbers beginning with "A" indicate genes on the larger plasmid.

c Name or predicted function.

d Weight matrix analysis.

e Evidence for expression or translocation is from $\mathrm{C}=$ Chang and associates. (2005), $\mathrm{R}=$ real-time polymerase chain reaction, or Table 3, as indicated.

f Avirulence (avr)/hop genes with HrpL-activated DC3000 homologs.

${ }^{\mathrm{g}}$ Referred to as hopF2 by Chang et al, 2005, phylogenetic comparison with the hop $F$ family indicates that this gene should be assigned to a new subgroup, hopF3.

${ }^{\mathrm{h}}$ Analysis of the region downstream indicates that the similarity with other members of the HopM1 family is prematurely truncated by an internal frameshift.

${ }^{\mathrm{i}}$ Genes without homologs in DC3000 effector families (Lindeberg et al. 2005).

j Referred to as $a v r B 3$ by Chang et al. (2005), phylogenetic comparison with the $a v r B$ family indicates that this gene should be assigned to a new subgroup, avrB4-1, with its non-HrpL regulated homolog (PSPPH0784) assigned the name $a v r B 4-2$.

${ }^{\mathrm{k}}$ Referred to as $a v r B 2-3$ by Chang et al. (2005) in an apparent typo in Table 1 of that work; the actual name is $a v r B 2$, as indicated in Chang et al. (2005) (Table 2).

${ }^{1}$ Referred to as hopK1 by Chang et al. (2005), this is in fact avrRps4 (hopK1 being a chimeric protein with similarity to avrRps4 at its N-terminus).

${ }^{\mathrm{m}}$ Genes with no apparent role in the type III secretion system (T3SS) that have HrpL-activated homologs in DC3000.

${ }^{\mathrm{n}}$ Confirmed hop genes with HMM2 scores falling below the cutoff.

${ }^{\circ}$ Referred to as hopAB2 by Chang et al. (2005), phylogenetic comparison with the hopAB family indicates that this is a member of the hopAB1 (virPphA) subgroup rather than the hopAB2 (avrPtoB) subgroup. 
three ORFs that do not have an apparent Hrp promoter preceding them, as well as the housekeeping gene gap-1 (PSPPH1176). Two genes associated with the $h r p / h r c$ cluster, PSPPH1273 ( $h r p Z 1)$ and PSPPH1295 ( $h r p K 1)$, provided positive controls. These genes have been shown in $P$. syringae pv. phaseolicola and other $P$. syringae pathovars to be regulated in an HrpL-dependent manner (Alfano et al. 2000; Guttman et al. 2002; Tamaki et al. 1988; Thwaites et al. 2004). All controls behaved as expected, and our data extend the findings of Chang and associates (2005) in establishing the predictive value of the HMM2 analysis.

\section{Translocation of Hop candidates using the Cya and AvrRpt2 reporter systems.}

We chose to test several HrpL-activated genes that appeared to encode Hops based on N-terminal T3SS targeting-associated patterns (Guttman et al. 2002; Petnicki-Ocwieja et al. 2002; Schechter et al. 2004). Those tested included candidate Avr/Hops encoded by PSPPH3028 (AvrB4-1), PSPPH4326 (HopAE1), PSPPH4736 (HopAS1), PSPPHA0031 (HopAU1), PSPPHA0113 (AvrD1), and PSPPHA0120 (AvrB2). AvrD1 was chosen for testing because it has been shown to produce syringolide elicitors of a cultivar-specific HR in soybean and, therefore, may not be translocated into plant cells like other typical Avr or effector proteins (Keen et al. 1990). Translational fusions at the $\mathrm{C}$-terminus to Cya enabled testing for translocation based on a calmodulin-dependent increase of cyclic AMP (cAMP) levels in plant cells (Casper-Lindley et al. 2002; Sory and Cornelis 1994). Quantification of cAMP was performed by infiltrating Nicotiana benthamiana leaves with $P$. fluorescens 55 containing a plasmid encoding either a wildtype or a nonfunctional T3SS (pLN18 and pCPP3297) and a second plasmid expressing the full-length test protein fused to Cya (pCPP3234) (Schechter et al. 2004).

All six 1448A Avr/Hop proteins, as well as known effector AvrPto1 from P. syringae pv. tomato (Schechter et al. 2004) produced an increased level of cAMP in leaves when they were expressed with a functional T3SS (Table 3), indicating that these proteins are translocated. Furthermore, PSPPH 3028
(avrB4-1) and PSPPH4326 (hopAE1) are translocated at a level comparable with the well-characterized type III secretion substrate AvrPto1. PSPPHA0113 (AvrD1) and PSPPHA0031 (HopAU1) also can be translocated into plant cells, but at a much lower level. Two proteins unlikely to be Hops also were included in these studies as negative controls; PSPPH1127 is a protein with similarity to a lipoprotein in Ralstonia solanacearum and does not have a Hrp promoter preceding the coding sequence, and PSPPH3960 is similar to a predicted signal transduction protein and also lacks a Hrp promoter or target-

Table 3. Translocation tests based on calmodulin-dependent adenylate cyclase activity of Pseudomonas syringae pv. phaseolicola candidate proteins in planta

\begin{tabular}{lcc}
\hline & $\begin{array}{c}\text { Translocation by } \text { P. } \text { fluorescens } \\
\text { (pmol of cAMP per } \\
\text { microgram of protein) }\end{array}$ \\
\cline { 2 - 3 } Protein fused to Cya & pLN18 & pCPP3297 $^{\mathbf{a}}$ \\
\hline PSPPH3028 (AvrB4-1) & $170.7 \pm 14.2$ & $0.5 \pm 0.0$ \\
PSPPH4326 (HopAE1) & $332.9 \pm 8.3$ & $3.8 \pm 0.7$ \\
PSPPH4736 (HopAS1) & $33.8 \pm 3.6$ & $0.7 \pm 0.1$ \\
PSPPHA0031 (HopAU1) & $3.6 \pm 0.8$ & $0.5 \pm 0.1$ \\
PSPPHA0113 (AvrD1) & $5.3 \pm 1.7$ & $1.2 \pm 0.6$ \\
PSPPHA0120 (AvrB2) & $68.1 \pm 20.0$ & $0.3 \pm 0.0$ \\
PSPPH1127 (putative lipoprotein) & $0.7 \pm 0.3$ & $0.5 \pm 0.2$ \\
PSPPH3960 (putative regulator) & $0.3 \pm 0.1$ & $0.3 \pm 0.2$ \\
AvrPto1 & $172.3 \pm 22.7$ & - \\
\hline
\end{tabular}

${ }^{\text {a }}$ Cyclic AMP (cAMP) levels in Nicotiana benthamiana leaf samples were quantified in triplicate at $7 \mathrm{~h}$ postinoculation with $P$. fluorescens (optical density at $600 \mathrm{~nm}=0.3$ ) containing a cosmid expressing either a wildtype (pLN18) or $\triangle h r c C$ mutant (pCPP3287) hypersensitive response and pathogenicity (Hrp) system from $P$. syringae pv. syringae 61. A plasmid expressing an AvrPto1-Cya fusion from P. syringae pv. tomato was used as a positive control. The Cya fusion protein corresponds to the first open reading frame downstream of the respective Hrp promoter. The values presented are the means and standard deviation from three samples. Repeated experiments yielded similar results.

${ }^{b}$ HopAE1-Cya was assayed in a separate experiment in which the AvrPto1-Cya reference yielded $198.3 \pm 113.0$ pmol of cAMP per microgram of protein.

Table 2. HrpL-dependent expression in rich media of 14 Pseudomonas syringae pv. phaseolicola 1448A genes downstream of hypersensitive response and pathogenicity (Hrp) promoters, as measured by real-time polymerase chain reaction

\begin{tabular}{|c|c|c|c|c|c|}
\hline PSPPH no. ${ }^{a}$ & Name or predicted function & HMM2 $^{\text {b }}$ & $\Delta(\text { Log concentration })^{c}$ & Fold induction $^{\mathrm{d}}$ & Induced $^{\mathrm{e}}$ \\
\hline 1269 & Lytic murein transglycosylase & 18.1 & $0.33 \pm 0.21$ & 2.14 & + \\
\hline 1273 & hrpZl & 15.9 & $0.95 \pm 0.27$ & 8.99 & + \\
\hline 1295 & hrpKl & 17.5 & $0.68 \pm 0.29$ & 4.80 & + \\
\hline 1519 & SlyA/MarR family & 12.5 & $0.1 \pm 0.26$ & 1.25 & \pm \\
\hline 1525 & ARM protein & 22.6 & $0.17 \pm 0.23$ & 1.49 & + \\
\hline 1855 & ApbE family & 22.7 & $0.38 \pm 0.29$ & 2.41 & + \\
\hline 3028 & avrB4-1 & 18.8 & $0.42 \pm 0.21$ & 2.60 & + \\
\hline 3759 & Alcohol dehydrogenase & 20.6 & $0.44 \pm 0.18$ & 2.73 & + \\
\hline 4326 & hopAE1 & 17.2 & $0.65 \pm 0.21$ & 4.42 & + \\
\hline 4736 & hopAS1 & 15.9 & $0.23 \pm 0.1$ & 1.68 & + \\
\hline A0031 & hоpAU1 & 12.3 & $0.31 \pm 0.15$ & 2.04 & + \\
\hline A0113 & avrD1 & 23 & $0.53 \pm 0.4$ & 3.40 & + \\
\hline A0120 & avrB2 & 16.1 & $0.21 \pm 0.1$ & 1.64 & + \\
\hline 3960 & Putative regulator & - & $0.03 \pm 0.07$ & 1.07 & - \\
\hline 1381 & Deoxycytidine triphosphate deaminase & - & $0.02 \pm 0.09$ & 1.04 & - \\
\hline 1127 & Lipoprotein & - & $0.02 \pm 0.03$ & 1.05 & - \\
\hline 1176 & gap-1 & - & $0.04 \pm 0.19$ & 1.09 & - \\
\hline
\end{tabular}

${ }^{a}$ Gene designation corresponds to the PSPPH number of the open reading frame presented in ascending order except for the three negative controls at the bottom

${ }^{\mathrm{b}} \mathrm{HMM}=$ hidden Markov model.

${ }^{\mathrm{c}} \log (\Delta$ concentration $)$ is the difference of the logarithm of relative mRNA concentrations between $1448 \mathrm{~A}$ strains carrying the plasmid $\mathrm{pML} 122$ and pCPP2308, respectively. A housekeeping gene, gap-1 (PSPPH1176), as well as two genes that are not preceded by an Hrp promoter, (PSPPH1381 and PSPPH1127), were used as negative controls. The values represent the mean and standard deviation from four independent analyses with two biological replicates for each sample. All genes were normalized to the expression of the housekeeping gene gyrA (PSPPH3667).

${ }^{\mathrm{d}}$ Fold induction was determined by reversing the log transformation: $10^{\Delta \log \text { concentration. }}$.

${ }^{\mathrm{e}}$ Symbols: + indicates significant HrpL regulation, - indicates no HrpL-dependent regulation, and \pm indicates that evidence of regulation was variable. 
ing-associated patterns. As expected, these proteins did not elevate the levels of cAMP in plant cells.

To further test whether PSPPHA0031 (HopAU1) and PSPPHA0113 (AvrD1) are translocated into plant cells, a second reporter system was used. AvrRpt $2_{(81-255)}$ fusions were constructed with full-length PSPPHA0031 and PSPPH0113 proteins as previously described (Petnicki-Ocwieja et al. 2002) and inoculated into Arabidopsis accession Columbia (Col-0) wildtype RPS 2 or mutant rps 2 plants. AvrRpt 2 is an effector that elicits the HR when delivered into Arabidopsis carrying the RPS2 resistance gene (Mudgett and Staskawicz 1999). Previous studies have shown that a hybrid protein consisting of the biologically active C-terminal portion of the AvrRpt 2 protein and a type III N-terminal targeting signal from another Hop can elicit the HR in Arabidopsis in a T3SS-dependent manner in wild-type RPS2 but not in mutant rps 2 plants (Guttman and Greenberg 2001; Mudgett et al. 2000). We found that strains expressing PSPPH0031 and PSPPH0113 fused with AvrRpt $2_{(81-}$ 255) elicited the HR in RPS2 Arabidopsis plants but not in rps 2 Arabidopsis plants (Fig. 2). Positive controls in this experiment included a plasmid encoding a full-length AvrRpt 2 construct as well as a PSPPH4736(HopAS1)-AvrRpt $2_{(81-255)}$ fusion. PSPPH4736 was chosen as a positive control because it gave conclusive results in the Cya translocation assay (Table 3). Negative controls included a plasmid encoding a hybrid protein of full-length PSPPH1127 (a putative lipoprotein that is not produced in a HrpL-dependent manner and does not have type III targeting signal patterns) as well as AvrRpt $2_{(81-255)}$, which is biologically active in planta but lacks targeting signals for translocation by the T3SS (Mudgett et al. 2000). Designations for all of the plasmids used are listed in Table 4. Because RPS2 protein mediates AvrRpt2 recognition within plant cells (Axtell and Staskawicz 2003; Mackey et al. 2003), the rps2 mutant provides further control for T3SS-dependent translocation of the test proteins.

\section{Analysis of $P$. syringae pv. tomato DC3000 mutants involving genes that are activated by $\mathrm{HrpL}$ in both DC3000 and 1448A but do not appear to have a function related to the T3SS.}

Two genes in the 1448A HrpL regulon that have homologs in DC3000 that were experimentally confirmed to be activated by HrpL in DC3000 are identified in Table 1. PSPPH1855 (ApbEfamily protein) and PSPPH3759 (alcohol dehydrogenase) appear to have no function related to the T3SS and they have predicted enzymatic activities that may provide clues to metabolic adaptations that bacteria make during T3SS-mediated pathogenesis. The association of the two genes with Hrp promoters in two phylogenetically divergent pathovars suggests that they direct responses that are broadly important in $P$. syringae infection. As a first step in the exploration of these genes, we used pKnockout- $\Omega$ (Windgassen et al. 2000) to construct mutations in the model strain DC3000, which ablated PSPTO2105 (PSPPH1855 ApbE-family protein) and PSPTO0834 (PSPPH3759 alcohol dehydrogenase homolog), to produce mutants CUCPB5390 and CUCPB5391, respectively. We chose to use DC3000 here because more is known about this strain and we were able to assay for subtle virulence effects in the model plant Arabidopsis. PSPTO2105 appears to be in a monocistronic operon and is separated from the downstream PSPTO2106 by 139 nucleotides, a distance that exceeds that of predicted members of the same operon (Moreno-Hagelsieb and Collado-Vides 2002). In contrast, PSPTO0834 is the first gene in what appears to be an operon comprising five genes. The orientation of the pKnockout- $\Omega$ insertion in PSPTO0834, as determined by sequencing, would permit transcription of downstream genes from

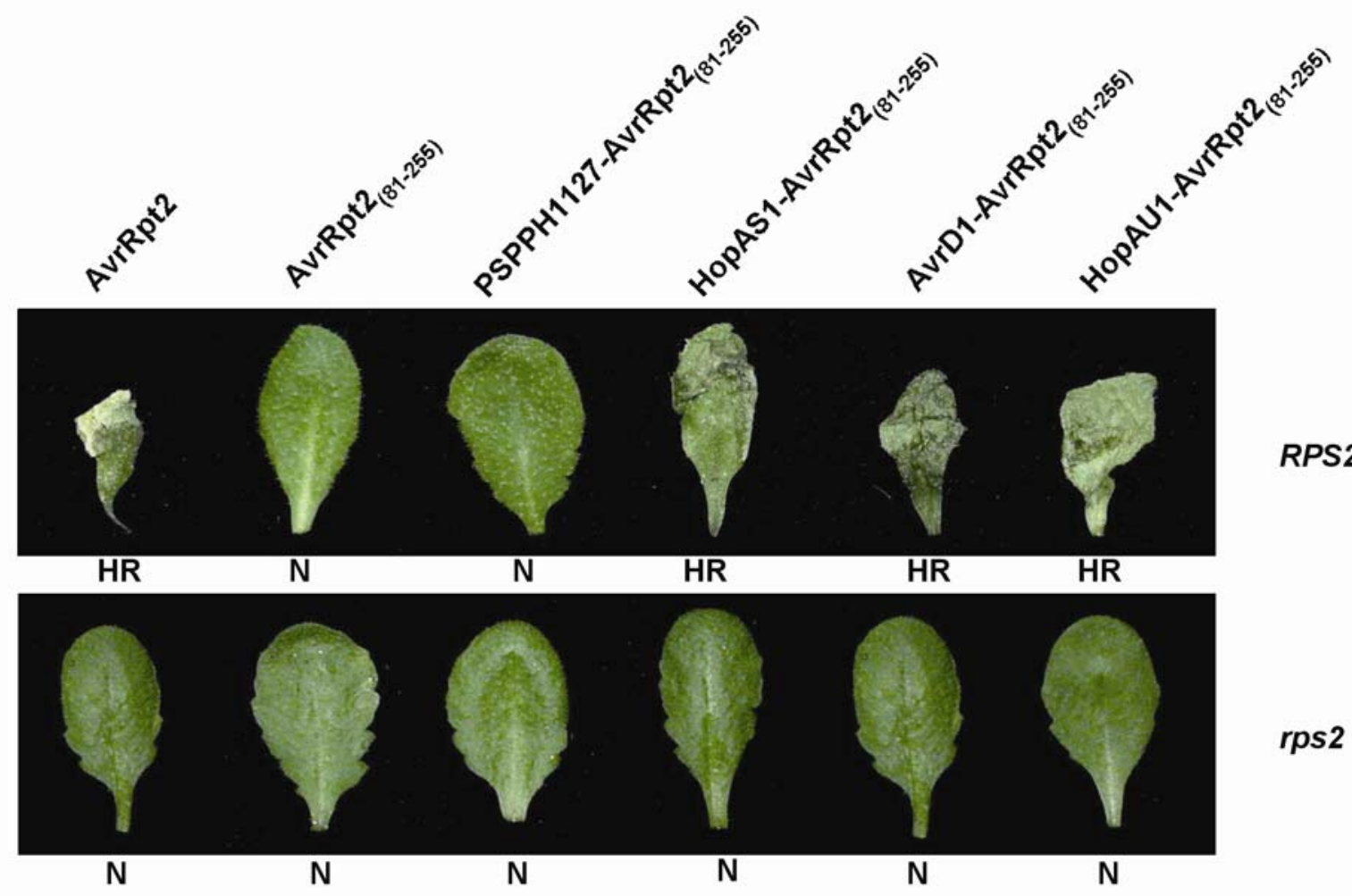

Fig. 2. Assay for hypersensitive response and pathogenicity (Hrp)-dependent translocation of candidate effector proteins. Pseudomonas syringae pv. phaseolicola 1448A cells carrying the tested proteins fused to AvrRpt2 were infiltrated into Arabidopsis Col-0 (RPS2) and Col-0-201 (rps2) plants. Strains expressing the full-length AvrRpt2 and AvrRpt $2_{(81-255)}$ were used as positive and negative controls, respectively. Plant responses were scored 24 hrs after inoculation for hypersensitive response (HR) or no visible response $(\mathrm{N})$. 
an outreading lac promoter (Windgassen et al. 2000). Arabidopsis plants were inoculated by vacuum infiltration with DC3000, CUCPB5390, and CUCPB5391 at $1 \times 10^{6} \mathrm{CFU} / \mathrm{ml}$. PSPTO2105 (ApbE homolog) mutant CUCPB5390 produced noticeably reduced symptoms at 4 and 8 days postinoculation, and both mutants showed reduced growth in planta (Fig. 3).

\section{DISCUSSION}

We have comprehensively identified $P$. syringae pv. phaseolicola 1448A Hrp promoters and type III effectors using two bioinformatic tools that were developed through previous analysis of the model pathogen $P$. syringae pv. tomato DC3000. The HMM tool enabled us to identify 44 high-probability Hrp promoters, and T3SS targeting signal patterns enabled us to identify 27 candidate effectors and related T3SS substrates. The inventory of predicted promoters and effectors generally is congruent with that found through a near-saturation DFI-based screen for type III effectors in $P$. syringae pv. phaseolicola (Chang et al. 2005). However, we have gained evidence for three additional 1448A proteins that can be translocated into plant cells by the T3SS. The majority of the Hrp promoters in
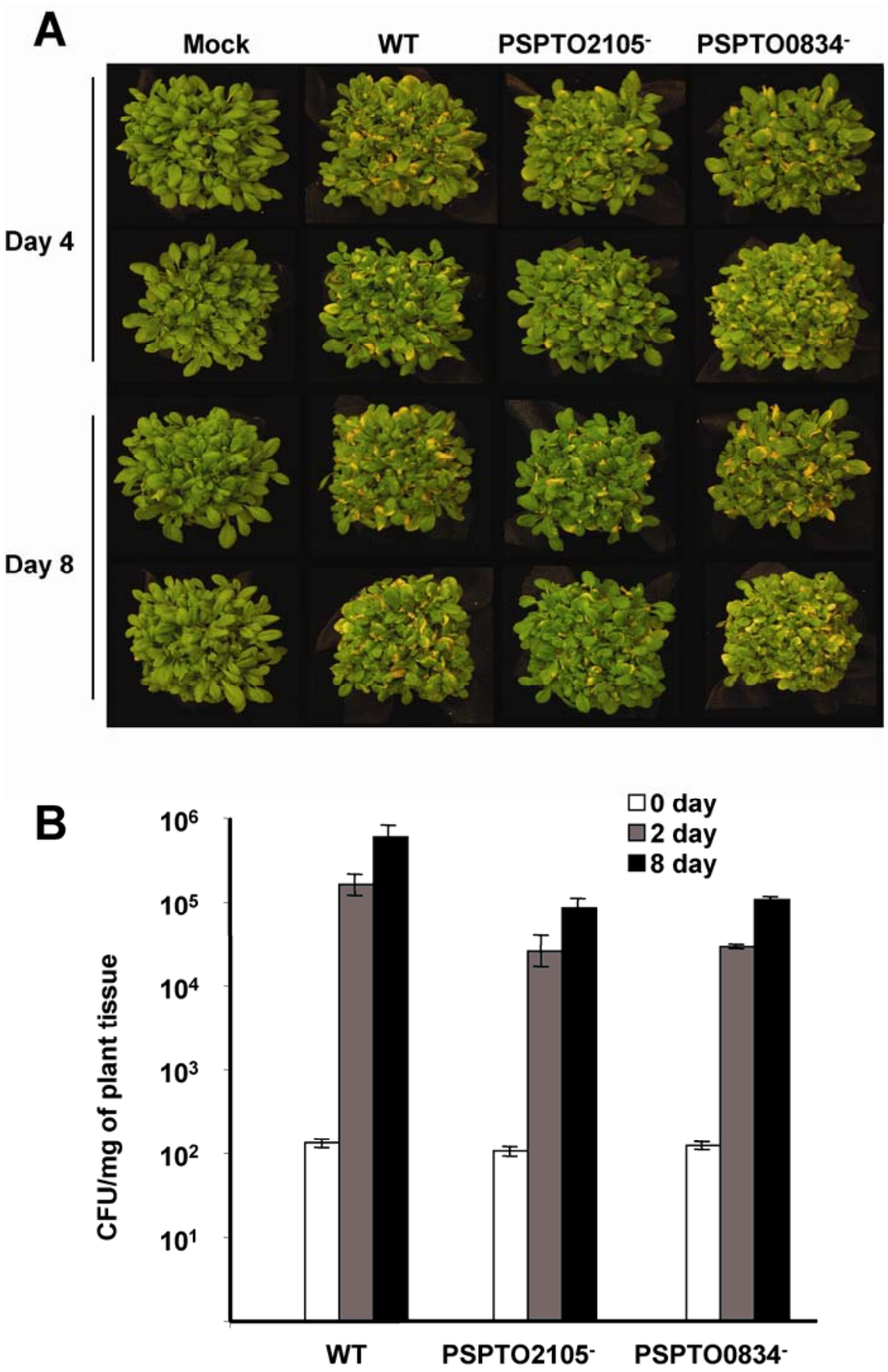

Fig. 3. Assay for reduced virulence in Arabidopsis of Pseudomonas syringae pv. tomato DC3000 mutants deficient in PSPTO2105 (PSPPH1855 ApbE homolog) and PSPTO0834 (PSPPH3759 alcohol dehydrogenase homolog). Arabidopsis Col-0 plants were inoculated by vacuum infiltration of wild-type DC3000, CUCPB5390 (PSPTO2105::pKnockout- $\Omega$ ), and CUCPB5391 (PSPTO0834::pKnockout- $\Omega$ ) at $1 \times 10^{6} \mathrm{CFU} / \mathrm{ml}$. A, Representative symptoms 4 and 8 days after inoculation. B, Bacterial growth at 0,2 , and 8 days after inoculation. Results are the mean and standard deviation of six samples from three plants. The experiment was repeated four times with similar results. 
DC3000 activate genes directing the T3SS, effectors, and related substrates, and only 10 appear to have functions not directly related to the T3SS. Genes that function independently of the T3SS and have been experimentally confirmed to be in the HrpL regulons of both DC3000 and 1448A were of particular interest. Our data, along with the microarray analysis of DC3000 (Ferreira et al. 2006) and the DFI screens of both DC3000 and 1448A (Chang et al. 2005), permit comprehensive comparison of the HrpL regulons and effector inventories of these two strains.

The three novel effectors we identified in 1448A were PSPPH4326 (HopAE1), PSPPH4736 (HopAS1), and PSPPHA0113 (AvrD1). The relatively low induction ratio observed for the hopAS1 promoter is consistent with it being missed in the DFI screen of Chang and associates (2005). In contrast, avrDl was detected in the DFI screen, but an AvrD1AvrRpt $2_{(81-255)}$ fusion driven by its native promoter failed to elicit an HR in Arabidopsis that would be indicative of translocation (Chang et al. 2005). Here, we gained evidence that AvrD1 can be translocated by using assays that employ a tac promoter and both the Cya and AvrRpt $2_{(81-255)}$ translocation reporters. hopAE1 was not detected by the DFI screen but is strongly induced by HrpL, and its product is strongly translocated. Furthermore, its homolog in P. syringae pv. syringae $\mathrm{B} 728 \mathrm{a}$ was shown to be translocated (Vinatzer et al. 2005); therefore, HopAE1 represents an effector that is lacking from DC3000 but present in two divergent pathovars that are pathogens of bean.
AvrD1 warrants further discussion because it is unlike other known $P$. syringae Avr proteins in its production of a low molecular weight cultivar-specific elicitor of the HR (Keen et al. 1990). AvrD1 directs the production of syringolides that can be isolated from culture fluids of Escherichia coli or P. syringae cells expressing $a v r D 1$, and these syringolides elicit the HR in cultivars of soybean that are resistant to races of $P$. syringae pv. glycinea that naturally carry avrDl (Keen et al. 1990; Midland et al. 1995; Smith et al. 1993). Bacteria expressing avrD1 do not need the Hrp T3SS to produce active elicitor in their culture fluids but, interestingly, $P$. syringae pv. glycinea needs the Hrp T3SS to elicit an avrDl-dependent HR when bacterial cells, rather than culture fluids, are introduced into sensitive soybean cultivars (Keen et al. 1990). In contrast, $E$. coli cells expressing avrD1 without the Hrp T3SS could elicit the HR in test soybean cultivars, apparently because of stronger expression of $a v r D 1$ in E. coli. These results raise the possibility that AvrD1 can produce syringolides from common metabolites in either the bacterium or the plant; and, in natural infections involving T3SS-proficient $P$. syringae pv. glycinea, it is the syringolide produced in plant cells by translocated AvrD1 that is biologically relevant. Our data do not demonstrate whether AvrD1 can produce syringolides within plant cells, but they do demonstrate, with two different reporters, that AvrD1 can be translocated into plant cells by the T3SS. Regarding the AvrRpt $2_{(81-255)}$ reporter, it is important to note that the failure of the AvrD1-AvrRpt $2_{(81-255)}$ hybrid to elicit the

Table 4. Strains and plasmids used

\begin{tabular}{|c|c|c|}
\hline Strain or plasmid & Genotype or relevant phenotype ${ }^{a}$ & Source or reference \\
\hline \multicolumn{3}{|l|}{ Escherichia coli strains } \\
\hline TOP10 & $\mathrm{F}^{-}$mcrA $\Delta(m r r-h s d R M S-m c r B C) \phi 80 l a c Z \Delta \mathrm{M} 15 \Delta$ lacX74 deoR recA1 araD139 & \\
\hline & $\Delta($ ara-leu $) 7697$ galU galK rpsL endA1 пирG & Invitrogen \\
\hline E. coli $\mathrm{DH} 5 \alpha$ & supE44 DlacU169( $880 l a c Z D M 15)$ hsdR17 recAl endA1 gyrA96 thi-1 relA1, $\mathrm{Nx}^{\mathrm{r}}$ & Life Technologies; Hanahan 1983 \\
\hline DB3.1 & $\begin{array}{l}\mathrm{F}^{-} \text {gyrA462 endA1 } \Delta(\text { srl-recA) mcrB mrr hsdS20 supE44 ara-14 galK2 lacY1 proA2 } \\
\text { rpsL20 xyl-5 } \lambda^{-} \text {leu mtl-1 }\end{array}$ & Invitrogen \\
\hline \multicolumn{3}{|l|}{ Pseudomonas syringae } \\
\hline pv. phaseolicola $1448 \mathrm{~A}$ & Wild type, Rif $^{\mathrm{T}}$ & Joardar et al. 2005 \\
\hline pv. tomato DC3000 & Wild type, Rif $^{r}$ & Cuppels 1986 \\
\hline CUCPB5390 & PSPTO2105::pKnockout- $\Omega$ derivative of DC3000 (using 768-bp internal fragment) & \\
\hline & $\mathrm{Sp}^{\mathrm{r}}, \mathrm{St}^{\mathrm{r}}$ & This work \\
\hline CUCPB5391 & $\begin{array}{l}\text { PSPTO0834::pKnockout- } \Omega \text { derivative of DC3000 (using 536-bp internal fragment) } \\
\mathrm{Sp}^{\mathrm{r}}, \mathrm{St}^{\mathrm{r}}\end{array}$ & This work \\
\hline P. fluorescens 55 & Wild type, $\mathrm{Nx}^{\mathrm{r}}, \mathrm{Sp}^{\mathrm{r}}$ & Huang et al. 1988 \\
\hline \multicolumn{3}{|l|}{ Plasmids } \\
\hline pLN18 & $\begin{array}{l}\text { pLAFR } 3 \text { derivative containing } P \text {. syringae } 61 \text { hrc-hrp cluster with } s h c A \text { and hopPsyA } \\
\text { replaced by an } n p t I I \text { cassette, } \mathrm{Tc}^{\mathrm{r}}, \mathrm{Km}^{\mathrm{r}}\end{array}$ & Jamir et al. 2004 \\
\hline pLN921 & pBBR1-MCS5 derivative containing 'avrRpt2 lacking $\mathrm{N}$-terminal 80 residues, $\mathrm{Gm}^{\mathrm{r}}$ & Petnicki-Ocwiega et al. 2005 \\
\hline pAvrRpt2-600 & pDSK600 derivative containing full-length avrRpt2, $\mathrm{Sp}^{\mathrm{r}} / \mathrm{Sm}^{\mathrm{r}}$ & Pirhonen et al. 1996 \\
\hline pML122 & RSF1010-derived broad-host-range expression vector, $\mathrm{Gm}^{\mathrm{r}}$ & Labes et al. 1990 \\
\hline pCPP2308 & pML122 carrying $h r p L$ from $P$. syringae pv. syringae $61, \mathrm{Gm}^{\mathrm{r}}$ & David Bauer, Cornell University \\
\hline pCPP3297 & pLN18 containing an unmarked deletion in $h r c C, \mathrm{Tc}^{\mathrm{r}}, \mathrm{Km}^{\mathrm{r}}$ & Schechter et al. 2004 \\
\hline pCPP3234 & 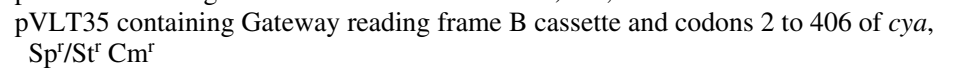 & Schechter et al. 2004 \\
\hline pCPP5186 & pCPP3234 expressing PSPPH3960-Cya, $\mathrm{Sp}^{\mathrm{r}} / \mathrm{St}^{\mathrm{r}} \mathrm{Cm}^{\mathrm{r}}$ & This study \\
\hline pCPP5187 & pCPP3234 expressing PSPPH3028-Cya, $\mathrm{Sp}^{\mathrm{r}} / \mathrm{St}^{\mathrm{r}} \mathrm{Cm}^{\mathrm{r}}$ & This study \\
\hline рСРP5188 & pCPP3234 expressing PSPPH1127-Cya, $\mathrm{Sp}^{\mathrm{r}} / \mathrm{St}^{\mathrm{r}} \mathrm{Cm}^{\mathrm{r}}$ & This study \\
\hline pCPP5189 & pCPP3234 expressing PSPPH4736-Cya, $\mathrm{Sp}^{\mathrm{r}} / \mathrm{St}^{\mathrm{r}} \mathrm{Cm}^{\mathrm{r}}$ & This study \\
\hline pCPP5191 & pCPP3234 expressing PSPPHA0113-Cya, $\mathrm{Sp}^{\mathrm{r}} / \mathrm{St}^{\mathrm{r}} \mathrm{Cm}^{\mathrm{r}}$ & This study \\
\hline pCPP5192 & pCPP3234 expressing PSPPHA0120-Cya, $\mathrm{Sp}^{\mathrm{r}} / \mathrm{St}^{\mathrm{r}} \mathrm{Cm}^{\mathrm{r}}$ & This study \\
\hline pCРP5193 & pCPP3234 expressing PSPPHA0031-Cya, $\mathrm{Sp}^{\mathrm{r}} / \mathrm{St}^{\mathrm{r}} \mathrm{Cm}^{\mathrm{r}}$ & This study \\
\hline pCPP3221 & pCPP3234 expressing AvrPto(1-164)-Cya, $\mathrm{Sp}^{\mathrm{r}} / \mathrm{St}^{\mathrm{r}} \mathrm{Cm}^{\mathrm{r}}$ & This study \\
\hline pLN1364 & pLN921 expressing PSPPH1127-AvrRpt $2_{(81-255}, \mathrm{Gm}^{\mathrm{r}}$ & This study \\
\hline pLN1403 & pLN921 expressing PSPPH4736-AvrRpt2 ${ }_{(81-255)}, \mathrm{Gm}^{\mathrm{r}}$ & This study \\
\hline pLN1365 & pLN921 expressing PSPPHA0113-AvrRpt $2_{(81-255)}, \mathrm{Gm}^{\mathrm{r}}$ & This study \\
\hline pLN1366 & pLN921 expressing PSPPHA0031-AvrRpt ${ }_{(81-255}, \mathrm{Gm}^{\mathrm{r}}$ & This study \\
\hline pKnockout $\Omega$ & $\mathrm{Sp}^{\mathrm{r}}, \mathrm{St}^{\mathrm{r}} m o b$ in T-vector & Windgassen et al. 2000 \\
\hline pKnockout- $\Omega::$ PSPTO0834 & Carries 539-bp internal fragment of PSPTO0834; $\mathrm{Sp}^{\mathrm{r}}, \mathrm{St}^{\mathrm{r}}$ & This study \\
\hline pKnockout- $\Omega:: P S P T O 2105$ & Carries 768-bp internal fragment of PSPTO2105; $\mathrm{Sp}^{\mathrm{r}}, \mathrm{St}^{\mathrm{r}}$ & This study \\
\hline
\end{tabular}

${ }^{\mathrm{a}} \mathrm{Nx}^{\mathrm{r}}, \mathrm{Rif}^{\mathrm{r}}, \mathrm{Gm}^{\mathrm{r}}, \mathrm{Km}^{\mathrm{r}}, \mathrm{Sp}^{\mathrm{r}}, \mathrm{Tc}^{\mathrm{r}}, \mathrm{Str}^{\mathrm{r}}, \mathrm{Cm}^{\mathrm{r}}$, and $\mathrm{Ap}^{\mathrm{r}}=$ nalidixic acid, rifampicin, gentamicin, kanamycin, spectinomycin, tetracycline, streptomycin, chloramphenicol, and ampicillin resistant, respectively. 
HR in rps 2 Arabidopsis plants eliminates the possibility that the HR observed in Arabidopsis by the hybrid is the result of AvrD1-dependent syringolide production in the bacterium. Future work will be required to determine whether the apparently low level of AvrD1 that can be translocated into plant cells is physiologically significant.

The "shikimate kinase-like" proteins encoded by PSPPH1525 and PSPPHA0133 also warrant discussion. Although both are similar to the mlr6331 and mlr6361 proteins of Mesorhizobium loti (MAFF303099), which contain AroKlike domains (COG0703) at the extreme C-terminus, this domain clearly is absent from PSPPH1525 and PSPPHA0133. However, the PSPPH1525 and PSPPHA0133 proteins contain an ARM-like domain (InterPro IPR011989), as do highly similar proteins from Xanthomonas and Ralstonia spp. The presence of upstream Hrp promoters and of two of the three major targeting-associated patterns suggests that these two ARM-like proteins in 1448A could be T3SS substrates. Ralstonia solanacearum proteins containing ARM-like domains are similarly believed to be T3SS effectors (Gabriel et al. 2006). However, because of the large size of PSPPH1525 and PSPPHA0133, we were unable to construct full-length Cya fusions and did not test the ability of these proteins to travel the T3SS.

Our current knowledge of the composition and function of the type III effector inventories of $P$. syringae strains indicates a mix of conserved and polymorphic effectors and a primary role of effectors in suppressing basal resistance and manipulating cell death pathways in plants (Alfano and Collmer 2004; Nomura et al. 2005). However, we have little knowledge of other factors that may have a role in either basic parasitism or host specificity. We looked for clues in other genes in the HrpL regulon that appear to function independently of the T3SS. The HrpL regulons of DC3000 and 1448A revealed several interesting differences regarding toxins, phytohormone metabolism, and plant cell-wall-degrading enzymes. Coronatine biosynthesis genes are activated by HrpL in DC3000, but there is no evidence that genes associated with phaseolotoxin or any other phytotoxin are activated by the HrpL regulon of 1448A. Similarly, iaaL is in the HrpL regulon of DC3000 but not 1448A (Chang et al. 2005; Fouts et al. 2002). On the other hand, we have found that two polygalacturonases are associated with Hrp promoters in 1448A. Although coronatine has an established role in the virulence of DC3000 (Brooks et al. 2004; Mittal and Davis 1995), there is no evidence that coronatine or any of these factors are involved in the host specificity of any $P$. syringae pathovars.

Genes unrelated to the T3SS that nevertheless are common to the HrpL regulons of divergent pathovars may have a role in basic parasitism in all plants. We explored two pairs of such genes: PSPPH1855/PSPTO2105 (ApbE-family) and PSPPH3759/PSPTO0834 (alcohol dehydrogenase). PSPPH1855 was missed by the DFI screen (Chang et al. 2005), but it is preceded by a Hrp promoter and was confirmed to be HrpL activated by real-time PCR. Furthermore, the DC3000 homolog was identified in an in vivo expression technology (IVET) screen for genes expressed during infection of Arabidopsis (Boch et al. 2002), and it was also shown to be coregulated with hrp genes in culture (Zwiesler-Vollick et al. 2002). Furthermore, a similar ApbE-family protein gene in $P$. syringae pv. syringae $\mathrm{B} 728 \mathrm{a}$ was found to be induced during epiphytic growth on healthy leaves (Marco et al. 2005), which suggests that these proteins may be broadly important in $P$. syringae-plant interactions.

The PSPPH1855/PSPTO2105 ApbE-family proteins may play a role in protecting the bacteria from oxidative stress or other stresses found in the apoplastic environment. The Salmonella enterica serovar typhimurium homolog, $\mathrm{ApbE}$, is a peri- plasmic protein that is conditionally required for thiamine biosynthesis (Beck and Downs 1998, 1999), and there is evidence that the protein plays a role in $\mathrm{ThiH}$ Fe-S cluster repair to protect the bacterial cell from oxidative stress (Gralnick et al. 2000; Martinez-Gomez et al. 2004; Skovran and Downs 2003). The ApbE protein from $P$. syringae has a lipoprotein signal peptide detectable by LipoP. The predicted cleavage site is between residues 23 and 24. By analogy to ApbE, it is reasonable to presume that the mature PSPTO2105 gene product is localized to the periplasmic side of the inner membrane. However, the metabolic role of ApbE-family proteins in P. syringae and $S$. typhimurium appears to be quite different: the $a p b E$ mutant in DC3000 grows well without thiamine (data not shown), whereas the $a p b E$ mutant in $S$. typhimurium does not grow in the absence of thiamine. Interestingly, homologs of PSPPH1855/PSPTO2105 are found in $P$. aeruginosa and $P$. fluorescens, but they are not preceded by Hrp promoters.

The putative alcohol dehydrogenase encoded by PSPPH3759/ PSPTO0834 does not have a signal peptide detected by SignalP or LipoP. However, consensus methods such as Meta suggest that it assumes a three-dimensional structure resembling proteins from both eukaryotic and prokaryotic sources. The structure for a closely related protein from $P$. aeruginosa is available. Members of this class of proteins have a GroES-like N-terminal domain and an NAD(P)-binding Rossmann-fold domain at the $\mathrm{C}$-terminus. These proteins catalyze redox reactions involving a broad spectrum of alcohols. The structural predictions are insufficient to make detailed predictions regarding substrate specificity. PSPPH3759 and PSPTO0834 are located at the head of putative polycistronic operons containing four genes, but the existing annotation of the remaining genes does not provide any insight into their individual or collective roles. Orthologs of these four genes are missing from $P$. syringae pv. syringae $\mathrm{B} 728 \mathrm{a}, P$. aeruginosa, and $P$. fluorescens; interestingly, these genes are flanked by different mobile genetic elements in 1448A and DC3000.

We observed no reduction relative to wild-type DC3000 in the growth in King's B (KB) or Hrp minimal medium of the PSPTO2105::pKnockout- $\Omega$ mutant or the PSPTO0834:: pKnockout- $\Omega$ mutant (data not shown); however, both mutants were reduced in their ability to grow in Arabidopsis, and the PSPTO2105::pKnockout- $\Omega$ mutant produced symptoms that were discernibly milder upon repeated testing. Because of the relatively small reductions in growth and virulence, it is unlikely that these mutants would be detected in a screen for reduced virulence mutants. Thus, they demonstrate the power of using bioinformatic methods to identity candidate genes worthy of close scrutiny.

The data presented here for 1448A suggest that the bioinformatic methods honed with DC3000 are robust enough to predict accurately most of the effectors in any $P$. syringae strain and that this approach is more comprehensive and efficient than genetic screens, such as the DFI screen of Chang and associates (2005). The HMM2 analysis identified 38 of the $40 \mathrm{Hrp}$ promoters in 1448A that were identified by DFI, plus 3 that were not detected by DFI but were experimentally confirmed here: an ApbE-domain protein, HopAE1, and HopAS1. The two promoters we missed, which are upstream of hopABl and hopAT1, are preceded by atypical Hrp boxes, whose HMM2 scores are below the cutoff that captures all of the other effector genes. However, the WM2 scores for these promoters are above the cutoff that was developed based on our microarraybased analysis of the DC3000 HrpL regulon (Ferreira et al. 2006). Thus, they also can be identified by a comprehensive bioinformatic approach.

It also is important to note limitations in the bioinformatics approach that resulted in us missing three of the effectors 
found by Chang and associates (2005) during our analysis of the draft genome of 1448A: GLIMMER failed to identify the HopAW1 and HopAV1 ORFs, and the HopAT1 size was below the cutoff we used to identify candidate effectors. Importantly, the correct identification of start codons is a limiting factor in analyzing potential $\mathrm{N}$-terminal targeting-associated patterns. Type III effector genes are particularly problematic for genefinding programs because these genes often reside in genomic islands and islets with atypical percent GC content and codon usage. However, one useful lesson that we have learned from our analyses of the HrpL regulons of DC3000 and 1448A is that almost all high-probability Hrp promoters are within 200 bp of the start of an ORF. Thus, these promoters provide useful reference points for manual annotation of ORFs following automated gene finding. In summary, the bioinformatic protocol that we developed with the model P. syringae strain DC3000 and then tested here with 1448A should enable efficient identification of almost all type III effector genes and other interesting HrpL-regulated virulence genes in any strain of $P$. syringae.

\section{MATERIALS AND METHODS}

Bacterial strains, plasmids, and growth conditions.

The strains and plasmids used are listed in Table 4. All E. coli strains were grown in Luria-Bertani (LB) (Sambrook et al. 1989) or LM media (Hanahan 1983) at $37^{\circ} \mathrm{C}$. All Pseudomonas strains were grown in KB (King et al. 1954) or hrp-derepressing fructose minimal medium (Hrp MM) (Huynh et al. 1989). For the real-time PCR and Cya translocation assays, Pseudomonas strains were grown at $30^{\circ} \mathrm{C}$ and, for the AvrRpt 2 translocation assay, Pseudomonas strains were grown at $28^{\circ} \mathrm{C}$. For the real-time PCR and Cya translocation assays, antibiotics were used at the following concentrations: ampicillin, 100 $\mu \mathrm{g} / \mathrm{ml}$; chloramphenicol, $20 \mu \mathrm{g} / \mathrm{ml}$; kanamycin, $50 \mu \mathrm{g} / \mathrm{ml}$; rifampicin, $50 \mu \mathrm{g} / \mathrm{ml}$; and tetracycline, $10 \mu \mathrm{g} / \mathrm{ml}$. Because $P$. fluorescens 55 is resistant to spectinomycin, plasmids were maintained in this strain by using streptomycin at $100 \mu \mathrm{g} / \mathrm{ml}$ and tetracycline at $40 \mu \mathrm{g} / \mathrm{ml}$. For the AvrRpt 2 translocation assay, antibiotics were used at the following concentrations: kanamycin, $100 \mu \mathrm{g} / \mathrm{ml}$; chloramphenicol, $20 \mu \mathrm{g} / \mathrm{ml}$; gentamicin, $10 \mu \mathrm{g} / \mathrm{ml}$; rifampicin, $100 \mu \mathrm{g} / \mathrm{ml}$; and spectinomycin, $20 \mu \mathrm{g} / \mathrm{ml}$.

\section{Plant material.}

$N$. benthamiana plants were grown under greenhouse conditions and transferred to the laboratory 1 day prior to inoculation. During Cya translocation assays, $N$. benthamiana plants were maintained at $24^{\circ} \mathrm{C}$ with $10 \mathrm{~h}$ of light per day. Arabidopsis thaliana ecotype Columbia (Col-0) plants were grown in a growth chamber at $24^{\circ} \mathrm{C}$ with $10 \mathrm{~h}$ of light per day.

\section{Bioinformatic methods: Predicting operons.}

Preliminary operon predictions were made by using simple heuristic rules based on intergenic distances (Salgado et al. 2000) from the initial genome annotation (Joardar et al. 2005) and locations of REP sequences identified by HMMer (Tobes and Pareja 2005) and rho-independent transcription terminator sequences identified by TransTerm (Ermolaeva et al. 2000). Annotated genes on the same strand were assumed to be in the same operon if they were separated by less than $65 \mathrm{bp}$ with no intervening transcription terminator or REP sequence (G. Moreno-Hagelsieb, personal communication). Genes on opposite strands or separated by larger distances or intervening transcription terminator or REP sequences were assigned to separate operons. In most cases, these rules are consistent with more sophisticated prediction methods applied to the $P$. syringae pv. tomato DC3000 genome (Karp et al. 2005; Price et al. 2005). In a small number of instances, there is experimental data for operon structure in DC3000 and strong sequence conservation between the corresponding regions of $1448 \mathrm{~A}$ and DC3000; it was assumed that the corresponding operons in 1448A and DC3000 had the same structure.

\section{Bioinformatic methods: Hrp promoter searches using HMM and WM models.}

The level 2 training set from the accompanying article by Ferreira and associates (2006) was used to identify putative Hrp promoters in the $P$. syringae pv. phaseolicola 1448A genome sequence (Joardar et al. 2005). The methods of Fouts and associates (2002) and Fereirra and associates (2006) were modified as necessary. The overall bioinformatics workflow is schematically represented in Figure 1. Very briefly, the separately aligned subsets with 16- and 17-bp spacers between the nominal " -35 box" and " -10 box" were used to construct position-sensitive weight matrices (PSWM) using a whole-genome nucleotide dimer-based statistical background model and a suite of custom Python/BioPython scripts. PSWM scores are reported in relative units - the deviation from the mean divided by the standard deviation. The combined, aligned level 2 training set of Ferreira and associates (2006) and a whole-genome nucleotide monomer-based statistical background model were used to construct a calibrated HMM for scanning the 1448A genome sequence.

The orientation and distance to the nearest downstream gene were determined by examining the context in the annotated genome sequence. In some cases, putative Hrp promoters were identified upstream of anomalously long 5' untranslated regions or regions containing transposable elements. In these cases, very careful comparative analyses were conducted using $P$. syringae pv. tomato DC3000, P. syringae pv. syringae B728a, and other strains of $P$. syringae as well as Yersinia, Xanthomonas, and Ralstonia spp. to identify inconsistencies or omissions in the $1448 \mathrm{~A}$ genome annotation. New gene calls were made where substantial sequence conservation was detected with respect to putative genes in other species, strains, or elsewhere in the 1448A genome. The majority of changes could be traced to the association of Hrp promoters with regions of atypical nucleotide composition and proximity to transposable elements. The unusual nucleotide composition causes problems with most de novo gene-finding methods, and the appearance of small gene fragments created by transposition events presents severe difficulties for even expert annotators. Finally, the first examples of T3SS effector gene families are difficult to identify by sequence similarity searches because T3SS effectors tend to have unusual primary structure. In view of these facts, it is likely that the annotation of the regions containing Hrp promoters and genes encoding T3SS effectors will continue to be revised as genomes of related plant pathogens become available.

Putative Hrp promoters were required to have HMM scores greater than 10.0 or at least one PSWM score greater than 4.0, be located in an intergenic region, have the correct orientation with respect to the nearest downstream gene, and be within $220 \mathrm{bp}$ of the translation start codon for that gene. The putative and experimentally validated Hrp promoters have been submitted to National Center for Biotechnology Information as updates to the genome annotation.

\section{Bioinformatic methods: Identifying T3SS substrates via structure or composition rules.}

Novel hop genes were identified by analyzing the first two ORFs downstream of Hrp promoters for at least two of the following targeting-associated patterns in the $\mathrm{N}$-terminal regions of the predicted proteins: i) lack of acidic amino acids in the first 12 residues; ii) an Ile, Leu, Val, or Pro (or sometimes Ala) residue in position 3 or 4 but not in both, and often preceded 
by a Pro, polar, or basic amino acid; and iii) at least $10 \%$ Ser in the first 50 amino acids. Additional evidence for novel hop genes was sought through identification of associated class $1 \mathrm{~A}$ chaperones based on the presence of such a gene in the same operon as the candidate hop gene and on characteristics of the candidate chaperone: small size (10 to $20 \mathrm{kDa})$, acidic isoelectric point, and C-terminal amphipathic region (Parsot et al. 2003).

\section{Bioinformatic methods: Identifying T3SS effectors via protein-based similarity searching.}

Homologs in the P. syringae pv. phaseolicola 1448A genome of known effector genes in other strains of $P$. syringae were identified through tblastx of the 1448A genome using a single representative from each phylogenetically defined effector family and, where applicable, from each subfamily. An ORF was defined for each significant hit $\left(e\right.$ value $\left.<10^{-5}\right)$, and a comparison performed with the original query to identify truncated and degenerate loci. The designations for avr/hop genes and proteins in this report employ the recently adopted nomenclature system of Lindeberg and associates (2005), as maintained at the Pseudomonas-Plant Interaction website. Note that the 1448A HrpA pilus protein is now designated HrpA2 to reflect groupings revealed by a recent phylogenomic analysis of $h r p A$ genes in multiple pathovars of $P$. syringae (Inoue and Takikawa 2006).

\section{RNA preparation.}

All RNA extractions were performed using RNase-free tubes, filter tips, and equipment treated with RNAzap (Ambion, Austin, TX, U.S.A.). Real-time PCR grade water (Ambion) also was used for all procedures. A 2-ml overnight culture of each strain was grown in KB supplemented with rifampicin at $50 \mu \mathrm{g} / \mathrm{ml}$ and kanamycin at $50 \mu \mathrm{g} / \mathrm{ml}$. The cultures were reinoculated into $10 \mathrm{ml}$ of $\mathrm{KB}$ media supplemented with rifampicin at $50 \mu \mathrm{g} / \mathrm{ml}$ and kanamycin at $50 \mu \mathrm{g} / \mathrm{ml}$ to an optical density at $600 \mathrm{~nm}\left(\mathrm{OD}_{600}\right)$ of 0.1 and allowed to grow to an $\mathrm{OD}_{600}$ of 0.2 . One milliliter of culture then was centrifuged at $13,000 \times g$ for $5 \mathrm{~min}$, the supernatant was removed, and the cell pellet was flash frozen in liquid nitrogen. Total RNA was prepared from cell pellets using the SV Total RNA Isolation System from Promega according to the manufacturer's instructions. An additional DNase I digestion step was performed with DNA-free (Ambion) according to the rigorous DNase treatment included in the manufacturer's instructions. This additional DNase step was necessary to remove trace DNA contamination in the RNA preparation. RNA was further purified using the RNeasy Minikit (Qiagen, Hilden, Germany) following the manufacturer's instructions. Quantification and sample integrity of RNA samples was assessed using spectrophotometer readings of absorbance at $260 \mathrm{~nm}\left(\mathrm{~A}_{260}\right)$ and the $\mathrm{A}_{260 / \mathrm{A} 280}$ ratio, respectively.

\section{Real-time PCR.}

Real-time PCR was performed by using the ABI 7000 Sequence Detection System (Applied Biosystems, Foster City, CA, U.S.A.) and iTaq SYBR Green Supermix with Rox (BioRad, Richmond, CA, U.S.A.) following the manufacturer's protocols. Total RNA (100 ng) extracted from strains of $P$. $s y$ ringae pv. phaseolicola $1448 \mathrm{~A}$ was reverse transcribed in a thermocycler using a cDNA synthesis kit (Bio-Rad) according to the manufacturer's instructions. The resulting total cDNA population $(1 \mu \mathrm{l})$ was mixed with $0.3 \mu \mathrm{M}$ concentrations of each primer (Table 5) and $12.5 \mu$ l of master mix in a $25-\mu l$ final volume. The PCR assay was carried out with one cycle at $95^{\circ} \mathrm{C}$ for $2.5 \mathrm{~min}$ followed by 35 cycles of $95^{\circ} \mathrm{C}$ for $15 \mathrm{~s}$ and $60^{\circ} \mathrm{C}$ for $30 \mathrm{~s}$. The amount of fluorescence that resulted from the incorporation of the SYBR Green dye into double-stranded DNA was measured at the end of each cycle to determine the kinetics of PCR for each sample. DNA contamination and the formation of primer dimers were assessed by using controls lacking reverse transcriptase and template, respectively. The

Table 5. Primers for SYBR Green real time polymerase chain reaction (PCR) experiments (sequences are $5^{\prime}$ to $3^{\prime}$ )

\begin{tabular}{|c|c|c|}
\hline Target & Forward (upstream) primer & Reverse (downstream) primer \\
\hline \multicolumn{3}{|l|}{ For real-time PCR } \\
\hline PSPPH1269 & GCCAATGATCGAAAGCTCCTAC & AAAGATTGAAGCTGCGCCC \\
\hline PSPPH1273 & ACCGGACAACACGACTTGATG & TCGGAAAAACGAGTTCCGTC \\
\hline PSPPH1295 & CCCGATGTTCAGGAGTACCTCA & TTTGAACCTGCTCAGTCACGG \\
\hline PSPPH1525 & GCTCAAGGCTTACAGCATGGT & TCAACCCATTTCCCCAACTC \\
\hline PSPPH 1855 & ATGCATTGCCTGCCAATAGC & TCAGGTCGAAAGCACCATCAC \\
\hline PSPPH3028 & TCTCCCCAGTGGCATAATTCA & TTCCGGTGATCCAGACATAGC \\
\hline PSPPH 3759 & TTGCGAACCTTGCCGTCTT & CGCTCGGCAAAAGTTCCAT \\
\hline PSPPH3960 & GAAGATCGCGACGGTTTTGA & CGATCAGTGCCAACAGCAGTAA \\
\hline PSPPH4326 & TACGGCATGGGTTTCGATG & GGCACTTGGCAAATCACCA \\
\hline PSPPH4736 & CTGTCGCAGGTGACCTTAAAA & CCGGCTTATCCCATATCTGTGA \\
\hline PSPPHA0031 & AGACCTCAGCCAATTGCAGAC & CGTCGTGTACCCGAAAAGTTT \\
\hline PSPPHA0113 & AGTTTATCATTCCCGCCGCT & CGTCGATGAATTGAGTGCGA \\
\hline PSPPHA0120 & AATTGCTGGTGGCTCCATAGC & GCATCGCCCGAAAGAATTCT \\
\hline PSPPH3667 (gyrA) & GGTCGTGGACGCATTTACATG & TAAGCTGGTACGGCAGTTCGGT \\
\hline PSPPH1176 (gapl) & GTGCCCGCAAGGTCATTATCTC & AGATGATCTGGTGCGACTGACG \\
\hline PSPPH1381 & CGCAGACGAATTCAAGGTGTT & GCATACGTCGCTCTTGATATCG \\
\hline PSPPH1127 & CCAATGCCAACGATATTCAGG & ACTGGTGCCGTATTGCTTGAC \\
\hline PSPPH1127 & CCAATGCCAACGATATTCAGG & ACTGGTGCCGTATTGCTTGAC \\
\hline \multicolumn{3}{|c|}{ For cloning into $\mathrm{pENTR/SD/D-TOPO}$} \\
\hline PSPPH3028 & CACCATGGGATGCATTACTTCA & ATCATCAAACATTGACGGATACTG \\
\hline PSPPH4326 & CACCATGCGTGAAGATAAACACCC & TGCCGACTCCTCCGAGGTAG \\
\hline PSPPH4736 & CACCATGACCTTAAGAATCAATACTC & CGGCGGCGGAAACTGCG \\
\hline PSPPHA0031 & CACCGTGATTTTCGAACACTCATTGG & TTCCTGCTGCGTGCGGGCAC \\
\hline PSPPHA0113 & CACCATGCAAGACCTTAGCTT & GGGATTCTCGGCGATAA \\
\hline PSPPHA0120 & CACCATGGGAAATGTTTGTTTCCG & CTGAGGGGGCCGCTCAAAAA \\
\hline PSPPH1127 & CACCATGAACCTGCGTTATCTGAA & GTCAGTACCGTACTTCGGCG \\
\hline \multicolumn{3}{|c|}{ For mutagenesis using pKnockout- $\Omega$} \\
\hline PSPTO0834 & ACACCTACAAAAAGGGATGCGGGT & ACAATTCTCCCACCGCGACC \\
\hline PSPTO2105 & GTCGATCAACAGATGTCGCT & GCTTATCGGCACGAATCACA \\
\hline
\end{tabular}


production of nonspecific products was determined by the dissociation protocol included in the software provided with the ABI 7000 real-time PCR machine. The resulting cycle threshold $(\mathrm{Ct})$ values were calculated by the ABI 7000 software and analyzed using the relative standard curve method (separate tubes) described in ABI User Bulletin no. 2. In each strain, the $\mathrm{Ct}$ values of each gene tested were normalized to the $\mathrm{Ct}$ values of two housekeeping genes gyrA (PSPPH3667), and gap1(PSPPH1176) separately, and these values then were averaged to obtain relative expression data for each gene.

\section{Adenylate cyclase assay.}

Plasmids expressing C-terminal fusions of $P$. syringae pv. phaseolicola 1448A proteins with Cya were constructed and verified according to the methods described by Schechter and associates (2004). Briefly, candidate genes were cloned into the $\mathrm{pENTR/SD/D-TOPO}$ vector (Invitrogen, Carlsbad, CA, U.S.A.) following amplification off of genomic DNA using the primer pairs in Table 5. Plasmids containing candidate genes fused in frame to cya were constructed by recombining entry vectors with pCPP3234 using Gateway cloning technology (Invitrogen). The plasmids expressing the cya fusions were mated into $P$. fluorescens 55 isolates containing either pLN18 or pCPP3297. The $P$. fluorescens 55 strains expressing the Cya fusion proteins were grown on $\mathrm{KB}$ plates containing tetracycline at $40 \mu \mathrm{g} / \mathrm{ml}$ and streptomycin at $100 \mu \mathrm{g} / \mathrm{ml}$ and grown at $30^{\circ} \mathrm{C}$ for 2 days. In preparation for inoculation, bacterial cultures then were scraped and resuspended in $5 \mathrm{mM}$ morpholinoethanesulfonic acid (MES), $\mathrm{pH} 5.5$, supplemented with tetracycline at $40 \mu \mathrm{g} / \mathrm{ml}$ and streptomycin at $100 \mu \mathrm{g} / \mathrm{ml}$ with 100 $\mu \mathrm{M}$ IPTG, to an $\mathrm{OD}_{600}$ of 0.3 . Inoculation of 1 -month-old $N$. benthamiana plants and subsequent assay of adenylate cyclase activity both in plants at $7 \mathrm{~h}$ postinoculation and in $E$. coli strains during plasmid construction was performed according to the methods described by Schechter and associates (2004) using the Correlate-EIA cAMP immunoassay kit (Assay Designs, Ann Arbor, MI, U.S.A.) according to the manufacturer's instructions.

\section{AvrRpt2 translocation assays.}

The candidates tested were cloned into pLN921, which expresses AvrRpt 2 missing the first 80 residues. These constructs were electroporated into $P$. syringae pv. phaseolicola $1448 \mathrm{~A}$. The strains were infiltrated into Arabidopsis Col-0 and rps2 plants at an $\mathrm{OD}_{600}$ of 0.4 in $5 \mathrm{mM}$ MES, pH 5.6, by using a blunt syringe. Plant responses were scored $24 \mathrm{~h}$ after infiltration.

\section{Construction of mutant strains.}

Genes were disrupted in P. syringae pv. tomato DC3000 using pKnockout- $\Omega$ (Windgassen et al. 2000). Internal fragments of PSPTO0834 and PSPTO2105 were amplified using Extaq polymerase (Takara, Tokyo) using $1 \mu \mathrm{l}$ of each forward and reverse primer (Table 5), $12.5 \mu \mathrm{l}$ of Extaq, and $1 \mu \mathrm{l}$ of DC3000 genomic DNA in a $25-\mu \mathrm{l}$ reaction volume. An annealing temperature of 58 and $52^{\circ} \mathrm{C}$ was used for PSPTO0834 and PSPTO2105, respectively, and a 1 -min extension at $72^{\circ} \mathrm{C}$ was used to amplify both DNA fragments. The resulting PCR products were resolved on a $0.8 \%$ agarose gel, excised, and cleaned using the Qiagen gel extraction kit (Qiagen). Each DNA fragment $(60 \mathrm{fmol})$ then was ligated to $20 \mathrm{fmol}$ of $\mathrm{XcmI}$-digested pKnockout- $\Omega$ plasmid using T4 ligase (Invitrogen) for $1 \mathrm{~h}$ at room temperature according to the manufacturer's instructions. The resulting ligation products were electroporated into $E$. coli DH5 $\alpha$ cells, which were plated on LB media supplemented with spectinomycin and X-gal to select for the desired transformants. Putative transformants were checked by colony PCR for recombinant plasmids using the initial insert-specific primers. Plasmids were extracted from overnight cultures of $E$. coli $\mathrm{DH} 5 \alpha$ using the QIAprep Spin Miniprep Kit (Qiagen). Plasmid DNA (1 $\mu \mathrm{g})$ was electroporated into $50 \mu \mathrm{l}$ of DC3000 electrocompetent cells with $2 \mu \mathrm{l}$ of boiled salmon sperm DNA. After a 2 -h recovery period in liquid KB media, the cells were plated on KB plates supplemented with rifampicin and streptomycin to select for transformants. pKnockout plasmids are not able to replicate in DC3000; therefore, any colonies that grow on these plates have undergone a single crossover into the genome at the point of homology, thereby disrupting the target gene. Putative mutants were checked for disruption in the genome using PCR and primers specific for an area within the genome and the pKnockout $\Omega$ plasmid.

\section{Virulence assay.}

Wild-type DC3000 and mutant strains were grown for 2 days at $30^{\circ} \mathrm{C}$ on $\mathrm{KB}$ plates supplemented with rifampicin (50 $\mu \mathrm{g} / \mathrm{ml})$. The cells were resuspended to approximately $10^{6}$ $\mathrm{CFU} / \mathrm{ml}$ in water containing $0.01 \%$ Silwet and vacuum-infiltrated into 3-week-old Arabidopsis Col-0 plants. The infected plants were kept in a humid growth chamber at $25^{\circ} \mathrm{C}$ with a 14-h light cycle and were watered every 2 days. The plants were observed daily to follow the development of disease symptoms. In addition, leaf-associated bacteria were counted on days 0 (immediately after infection), 2 , and 8 by homogenizing the leaves in $10 \mathrm{mM} \mathrm{MgCl}$ buffer and spreading on $\mathrm{KB}$ plates supplemented with rifampicin $(50 \mu \mathrm{g} / \mathrm{ml})$ and cycloheximide $(2 \mu \mathrm{g} / \mathrm{ml})$. Mock infection without bacteria was included as a negative control.

\section{ACKNOWLEDGMENTS}

This work was supported by NSF Plant Genome Research Program Cooperative Agreement DBI-0077622. C. R. Myers acknowledges support from the United States Department of Agriculture-Agricultural Research Service under Specific Cooperative Agreement 5819074428 as part of project 1907-21000-009-00.

\section{LITERATURE CITED}

Alfano, J. R., Charkowski, A. O., Deng, W.-L., Badel, J. L., PetnickiOcwieja, T., van Dijk, K., and Collmer, A. 2000. The Pseudomonas syringae Hrp pathogenicity island has a tripartite mosaic structure composed of a cluster of type III secretion genes bounded by exchangeable effector and conserved effector loci that contribute to parasitic fitness and pathogenicity in plants. Proc. Natl. Acad. Sci. U.S.A. 97:4856-4861.

Alfano, J. R., and Collmer, A. 2004. Type III secretion system effector proteins: Double agents in bacterial disease and plant defense. Annu. Rev. Phytopathol. 42:385-414.

Arnold, D. L., Gibbon, M. J., Jackson, R. W., Wood, R. R., Brown, J., and Mansfield, J. W. 2001. Molecular characterization of avrPphD, a widely distributed plasmid-borne gene from Pseudomonas syringae pv. phaseolicola involved in non-host recognition by pea (Pisum sativum). Physiol. Mol. Plant Pathol. 58:55-62.

Axtell, M. J., and Staskawicz, B. J. 2003. Initiation of RPS2-specified disease resistance in Arabidopsis Is coupled to the AvrRpt2-directed elimination of RIN4. Cell 112:369-377.

Beck, B. J., and Downs, D. M. 1998. The $a p b E$ gene encodes a lipoprotein involved in thiamine synthesis in Salmonella typhimurium. J. Bacteriol. 180:885-891.

Beck, B. J., and Downs, D. M. 1999. A periplasmic location is essential for the role of the ApbE lipoprotein in thiamine synthesis in Salmonella typhimurium. J. Bacteriol. 181:7285-7290.

Boch, J., Joardar, V., Gao, L., Robertson, T. L., Lim, M., and Kunkel, B. N. 2002. Identification of Pseudomonas syringae genes induced during infection of Arabidopsis thaliana. Mol. Microbiol. 44:73-88.

Brooks, D., Hernandez-Guzman, G., Koek, A. P., Alarcon-Chaidez, F., Sreedharan, A., Rangaswarmy, V., Penaloza-Vasquez, A., Bender, C. L., and Kunkel, B. N. 2004. Identification and characterization of a welldefined series of coronatine biosynthetic mutants of Pseudomonas syringae pv. tomato DC3000. Mol. Plant-Microbe Interact. 17:162-174. 
Buell, C. R., Joardar, V., Lindeberg, M., Selengut, J., Paulsen, I. T., Gwinn, M. L., Dodson, R. J., Deboy, R. T., Durkin, A. S., Kolonay, J. F., Madupu, R., Daugherty, S., Brinkac, L., Beanan, M. J., Haft, D. H., Nelson, W. C., Davidsen, T., Liu, J., Yuan, Q., Khouri, H., Fedorova, N., Tran, B., Russell, D., Berry, K., Utterback, T., Vanaken, S. E., Feldblyum, T. V., D’Ascenzo, M., Deng, W.-L., Ramos, A. R., Alfano, J. R., Cartinhour, S., Chatterjee, A. K., Delaney, T. P., Lazarowitz, S. G., Martin, G. B., Schneider, D. J., Tang, X., Bender, C. L., White, O., Fraser, C. M., and Collmer, A. 2003. The complete sequence of the Arabidopsis and tomato pathogen Pseudomonas syringae pv. tomato DC3000. Proc. Natl. Acad. Sci. U.S.A. 100:10181-10186.

Casper-Lindley, C., Dahlbeck, D., Clark, E. T., and Staskawicz, B. J. 2002. Direct biochemical evidence for type III secretion-dependent translocation of the AvrBs2 effector protein into plant cells. Proc. Natl. Acad. Sci. U.S.A. 99:8336-8341.

Chang, J. H., Urbach, J. M., Law, T. F., Arnold, L. W., Hu, A., Gombar, S., Grant, S. R., Ausubel, F. M., and Dangl, J. L. 2005. A high-throughput, near-saturating screen for type III effector genes from Pseudomonas syringae. Proc. Natl. Acad. Sci. U.S.A. 102:2549-2554.

Cuppels, D. A. 1986. Generation and characterization of Tn5 insertion mutations in Pseudomonas syringae pv. tomato. Appl. Environ. Microbiol. 51:323-327

Ermolaeva, M. D., Khalak, H. G., White, O., Smith, H. O., and Salzberg, S. L. 2000. Prediction of transcription terminators in bacterial genomes. J. Mol. Biol. 301:27-33.

Ferreira, A. O., Myers, C. R., Gordon, J. S., Martin, G. B., Vencato, M., Collmer, A., Wehling, M. D., Alfano, J. R., Moreno-Hagelsieb, G., Lamboy, W. F., DeClerck, G., Schneider, D. J., and Cartinhour, S. W. 2006. Whole-genome expression profiling defines the HrpL regulon of Pseudomonas syringae pv. tomato DC3000, allows de novo reconstruction of the Hrp cis element, and identifies novel coregulated gene. Mol. Plant-Microbe Interact. 19:1167-1179.

Fouts, D. E., Abramovitch, R. B., Alfano, J. R., Baldo, A. M., Buell, C. R., Cartinhour, S., Chatterjee, A. K., D'Ascenzo, M., Gwinn, M. L., Lazarowitz, S. G., Lin, N.-C., Martin, G. B., Rehm, A. H., Schneider, D. J., van Dijk, K., Tang, X., and Collmer, A. 2002. Genomewide identification of Pseudomonas syringae pv. tomato DC3000 promoters controlled by the HrpL alternative sigma factor. Proc. Natl. Acad. Sci. U.S.A. 99:2275-2280.

Gabriel, D. W., Allen, C., Schell, M., Denny, T. P., Greenberg, J. T., Duan, Y. P., Flores-Cruz, Z., Huang, Q., Clifford, J. M., Presting, G., Gonzalez, E. T., Reddy, J., Elphinstone, J., Swanson, J., Yao, J., Mulholland, V., Liu, L., Farmerie, W., Patnaikuni, M., Balogh, B., Norman, D., Alvarez, A., Castillo, J. A., Jones, J., Saddler, G., Walunas, T., Zhukov, A., and Mikhailova, N. 2006. Identification of open reading frames unique to a select agent: Ralstonia solanacearum race 3 biovar 2. Mol. PlantMicrobe Interact. 19:69-79.

Gralnick, J., Webb, E., Beck, B., and Downs, D. 2000. Lesions in gshA (Encoding gamma-L-glutamyl-L-cysteine synthetase) prevent aerobic synthesis of thiamine in Salmonella enterica serovar typhimurium LT2. J. Bacteriol. 182:5180-5187.

Guttman, D. S., and Greenberg, J. T. 2001. Functional analysis of the type III effectors AvrRpt2 and AvrRpm1 of Pseudomonas syringae with the use of a single-copy genomic integration system. Mol. Plant-Microbe Interact. 14:145-155.

Guttman, D. S., Vinatzer, B. A., Sarkar, S. F., Ranall, M. V., Kettler, G., and Greenberg, J. T. 2002. A functional screen for the Type III (Hrp) secretome of the plant pathogen Pseudomonas syringae. Science 295:1722-1726.

Hanahan, D. 1983. Studies on transformation of Escherichia coli with plasmids. J. Mol. Biol. 166:557-580.

Huang, H.-C., Schuurink, R., Denny, T. P., Atkinson, M. M., Baker, C. J., Yucel, I., Hutcheson, S. W., and Collmer, A. 1988. Molecular cloning of a Pseudomonas syringae pv. syringae gene cluster that enables Pseudomonas fluorescens to elicit the hypersensitive response in tobacco plants. J. Bacteriol. 170:4748-4756.

Huynh, T. V., Dahlbeck, D., and Staskawicz, B. J. 1989. Bacterial blight of soybean: Regulation of a pathogen gene determining host cultivar specificity. Science 245:1374-1377

Innes, R. W., Bent, A. F., Kunkel, B. N., Bisgrove, S. R., and Staskawicz, B. J. 1993. Molecular analysis of avirulence gene avrRpt2 and identification of a putative regulatory sequence common to all known Pseudomonas syringae avirulence genes. J. Bacteriol. 175:4859-4869.

Inoue, Y., and Takikawa, Y. 2006. The hrpZ and hrpA genes are variable, and useful for grouping Pseudomonas syringae bacteria. J. Gen. Plant Pathol. 72:26-33.

Jackson, R. W., Athanassopoulos, E., Tsiamis, G., Mansfield, J. W., Sesma, A., Arnold, D. L., Gibbon, M. J., Murillo, J., Taylor, J. D., and Vivian, A. 1999. Identification of a pathogenicity island, which contains genes for virulence and avirulence, on a large native plasmid in the bean pathogen Pseudomonas syringae pathovar phaseolicola. Proc. Natl. Acad. Sci. U.S.A. 96:10875-10880.

Jamir, Y., Guo, M., Oh, H.-S., Petnicki-Ocwieja, T., Chen, S., Tang, X. Dickman, M. B., Collmer, A., and Alfano, J. R. 2004. Identification of Pseudomonas syringae type III secreted effectors that suppress programmed cell death in plants and yeast. Plant J. 37:554-565.

Jenner, C., Hitchin, E., Mansfield, J., Walters, K., Betteridge, P., Teverson, D., and Taylor, J. 1991. Gene-for-gene interactions between Pseudomonas syringae pv. phaseolicola and Phaseolus. Mol. Plant-Microbe Interact. 4:553-562.

Joardar, V., Lindeberg, M., Jackson, R. W., Selengut, J., Dodson, R., Brinkac, L. M., Daugherty, S. C., DeBoy, R., Durkin, A. S., Giglio, M. G., Madupu, R., Nelson, W. C., Rosovitz, M. J., Sullivan, S., Haft, D. H., Creasy, T., Davidsen, T., Zafar, N., Zhou, L., Halpin, R., Holley, T., Khouri, H., Feldblyum, T., White, O., Fraser, C. M., Chatterjee, Cartinhour, S., Schneider, D. J., Mansfield, J., Collmer, A., and Buell, C. R. 2005. Whole genome sequence analysis of Pseudomonas syringae pv. phaseolicola 1448A reveals sequence divergence among pathovars in genes involved in virulence and mobile genetic elements. J. Bacteriol. 187:6488-6498.

Karp, P. D., Ouzounis, C. A., Moore-Kochlacs, C., Goldovsky, L., Kaipa, P., Ahren, D., Tsoka, S., Darzentas, N., Kunin, V., and Lopez-Bigas, N. 2005. Expansion of the BioCyc collection of pathway/genome databases to 160 genomes. Nucleic Acids Res. 33:6083-6089.

Keen, N. T., Tamaki, S., Kobayashi, D., Gerhold, D., Stayton, M., Shen, H., Gold, S., Lorang, J., Thordal-Christensen, H., Dahlbeck, D., and Staskawicz, B. 1990. Bacteria expressing avirulence gene D produce a specific elicitor of the soybean hypersensitive reaction. Mol. PlantMicrobe Interact. 3:112-121.

King, E. O., Ward, M. K., and Raney, D. E. 1954. Two simple media for the demonstration of pyocyanin and fluorescin. J. Lab. Clin. Med. 44:301-307.

Labes, M., Puhler, A., and Simon, R. 1990. A new family of RSF1010derived expression and lac -fusion broad-host-range vectors for gramnegative bacteria. Gene 89:37-46.

Lindeberg, M., Stavrinides, J., Chang, J. H., Alfano, J. R., Collmer, A., Dangl, J. L., Greenberg, J. T., Mansfield, J. W., and Guttman, D. S. 2005. Proposed guidelines for a unified nomenclature and phylogenetic analysis of type III Hop effector proteins in the plant pathogen Pseudomonas syringae. Mol. Plant-Microbe Interact. 18:275-282.

Lindgren, P. B., Peet, R. C., and Panopoulos, N. J. 1986. Gene cluster of Pseudomonas syringae pv. "phaseolicola" controls pathogenicity of bean plants and hypersensitivity on nonhost plants. J. Bacteriol. 168:512-522.

Mackey, D., Belkhadir, Y., Alonso, J. M., Ecker, J. R., and Dangl, J. L. 2003. Arabidopsis RIN4 Is a target of the type III virulence effector AvrRpt2 and modulates RPS2-mediated resistance. Cell 112:379-389.

Marco, M. L., Legac, J., and Lindow, S. E. 2005. Pseudomonas syringae genes induced during colonization of leaf surfaces. Environ. Microbiol. 7:1379-1391.

Martinez-Gomez, N. C., Robers, M., and Downs, D. M. 2004. Mutational analysis of ThiH, a member of the radical S-adenosylmethionine (AdoMet) protein superfamily. J. Biol. Chem. 279:40505-40510.

Midland, S. L., Keen, N. T., and Sims, J. J. 1995. Secosyrins 1 and 2 and syributins 1 and 2: Novel structures produced by bacteria expressing the avrD gene. J. Org. Chem. 60:1118-1119.

Mittal, S., and Davis, K. R. 1995. Role of the phytotoxin coronatine in the infection of Arabidopsis thaliana by Pseudomonas syringae pv. tomato. Mol. Plant-Microbe Interact. 8:165-171.

Moreno-Hagelsieb, G., and Collado-Vides, J. 2002. A powerful non-homology method for the prediction of operons in prokaryotes. Bioinformatics 18(Suppl. 1):S329-336

Mudgett, M. B., and Staskawicz, B. J. 1999. Characterization of the Pseudomonas syringae pv. tomato AvrRpt2 protein: Demonstration of secretion and processing during bacterial pathogenesis. Mol. Microbiol. 32:927-941.

Mudgett, M. B., Chesnokova, O., Dahlbeck, D., Clark, E. T., Rossier, O., Bonas, U., and Staskawicz, B. J. 2000. Molecular signals required for type III secretion and translocation of the Xanthomonas campestris AvrBs2 protein to pepper plants. Proc. Natl. Acad. Sci. U.S.A 97:13324-13329.

Nomura, K., Melotto, M., and He, S. Y. 2005. Suppression of host defense in compatible plant-Pseudomonas syringae interactions. Curr. Opin. Plant Biol. 8:361-368.

Parsot, C., Hamiaux, C., and Page, A.L. 2003. The various and varying roles of specific chaperones in type III secretion systems. Curr. Opin. Microbiol. 6:7-14.

Petnicki-Ocwieja, T., Schneider, D. J., Tam, V. C., Chancey, S. T., Shan, L., Jamir, Y., Schechter, L. M., Buell, C. R., Tang, X., Collmer, A., and Alfano, J. R. 2002. Genomewide identification of proteins secreted by the Hrp type III protein secretion system of Pseudomonas syringae pv. 
tomato DC3000. Proc. Natl. Acad. Sci. U.S.A. 99:7652-7657.

Petnicki-Ocwiega, T., van Dijk, K., and Alfano, J. R. 2005. The hrpK operon of Pseudomonas syringae pv. tomato DC3000 encodes two proteins secreted by the type III (Hrp) protein secretion system: HopB1 and HrpK, a putative type III translocator. J. Bacteriol. 187:649-663.

Pirhonen, M. U., Lidell, M. C., Rowley, D. L., Lee, S. W., Jin, S., Liang, Y., Silverstone, S., Keen, N. T., and Hutcheson, S. W. 1996. Phenotypic expression of Pseudomonas syringae avr genes in E. coli is linked to the activities of the hrp-encoded secretion system. Mol. Plant-Microbe Interact. 9:252-260.

Price, M. N., Huang, K. H., Alm, E. J., and Arkin, A. P. 2005. A novel method for accurate operon predictions in all sequenced prokaryotes. Nucleic Acids Res. 33:880-892.

Puri, N., Jenner, C., Bennet, M., Stewart, R., Mansfield, J., Lyons, N., and Taylor, J. 1997. Expression of avrPphB, an avirulence gene from $\mathrm{Pseu}$ domonas syringae pv. phaseolicola, and the delivery of signals causing the hypersensitive reaction in bean. Mol. Plant-Microbe Interact. 10:247-256.

Salgado, H., Moreno-Hagelsieb, G., Smith, T. F., and Collado-Vides, J. 2000. Operons in Escherichia coli: Genomic analyses and predictions. Proc. Natl. Acad. Sci. U.S.A 97:6652-6657.

Sambrook, J., Fritsch, E. F., and Maniatis, T. 1989. Molecular Cloning: A Laboratory Manual, 2nd ed. Cold Spring Harbor Laboratory Press, Cold Spring Harbor, NY, U.S.A.

Sarkar, S. F., and Guttman, D. S. 2004. Evolution of the core genome of Pseudomonas syringae, a highly clonal, endemic plant pathogen. Appl. Environ. Microbiol. 70:1999-2012.

Sawada, H., Suzuki, F., Matsuda, I., and Saitou, N. 1999. Phylogenetic analysis of Pseudomonas syringae pathovars suggests the horizontal gene transfer of $\arg K$ and the evolutionary stability of $h r p$ gene cluster. J. Mol. Evol. 49:627-644.

Schechter, L. M., Roberts, K. A., Jamir, Y., Alfano, J. R., and Collmer, A 2004. Pseudomonas syringae type III secretion system targeting signals and novel effectors studied with a Cya translocation reporter. J. Bacteriol. 186:543-555

Schechter, L. M., Vencato, M., Jordan, K. L., Schneider, S. E., Schneider, D. J., and Collmer, A. 2006. Multiple approaches to a complete inventory of Pseudomonas syringae pv. tomato DC3000 type III secretion system effector proteins. Mol. Plant-Microbe Interact. 19:1180-1192.

Shen, H., and Keen, N. T. 1993. Characterization of the promoter of avirulence gene D from Pseudomonas syringae pv. tomato. J. Bacteriol. 175:5916-5924.

Skovran, E., and Downs, D. M. 2003. Lack of the ApbC or ApbE protein results in a defect in Fe-S cluster metabolism in Salmonella enterica serovar typhimurium. J. Bacteriol. 185:98-106.

Smith, M. J., Mazzola, E. P., Simms, J. J., Midland, S. L., Keen, N. T., Burton, V., and Stayton, M. M. 1993. The syringolides: Bacterial C-glycosyl lipids that trigger plant disease resistance. Tetrahedron Lett. 34:223-226

Sory, M.-P., and Cornelis, G. R. 1994. Translocation of a hybrid YopE-ade- nylate cyclase from Yersinia enterocolitica into HeLa cells. Mol. Microbiol. 14:583-594.

Tamaki, S., Dahlbeck, D., Staskawicz, B., and Keen, N. T. 1988. Characterization and expression of two avirulence genes cloned from Pseudomonas syringae pv. glycinea. J. Bacteriol. 170:4846-4854.

Thwaites, R., Spanu, P. D., Panopoulos, N. J., Stevens, C., and Mansfield, J. W. 2004. Transcriptional regulation of components of the type III secretion system and effectors in Pseudomonas syringae pv. phaseolicola. Mol. Plant-Microbe Interact. 17:1250-1258.

Tobes, R., and Pareja, E. 2005. Repetitive extragenic palindromic sequences in the Pseudomonas syringae pv. tomato DC3000 genome: Extragenic signals for genome reannotation. Res. Microbiol. 156:424-433.

Tsiamis, G., Mansfield, J. W., Hockenhull, R., Jackson, R. W., Sesma, A., Athanassopoulos, E., Bennett, M. A., Stevens, C., Vivian, A., Taylor, J. D., and Murillo, J. 2000. Cultivar-specific avirulence and virulence functions assigned to avrPphF in Pseudomonas syringae pv. phaseolicola, the cause of bean halo-blight disease. EMBO (Eur. Mol. Biol. Organ.) J. 19:3204-3214

Vinatzer, B. A., Jelenska, J., and Greenberg, J. T. 2005. Bioinformatics correctly identifies many type III secretion substrates in the plant pathogen Pseudomonas syringae and the biocontrol isolate $P$. fluorescens SBW25. Mol. Plant-Microbe Interact. 18:877-888.

Willis, D. K., and Kinscherf, T. G. 2004. Global regulation in Pseudomo nas syringae. Pages 223-238 in: Pseudomonas, Vol. 2. J. L. Ramos, ed. Kluwer Academic/Plenum Publishers, New York, U.S.A

Windgassen, M., Urban, A., and Jaeger, K. E. 2000. Rapid gene inactivation in Pseudomonas aeruginosa. FEMS (Fed. Eur. Microbiol. Soc.) Microbiol. Lett. 193:201-205.

Xiao, Y., and Hutcheson, S. 1994. A single promoter sequence recognized by a newly identified alternate sigma factor directs expression of pathogenicity and host range determinants in Pseudomonas syringae. J. Bacteriol. 176:3089-3091.

Zwiesler-Vollick, J., Plovanich-Jones, A. E., Nomura, K., Brandyopadhyay, S., Joardar, V., Kunkel, B. N., and He, S. Y. 2002. Identification of nove hrp-regulated genes through functional genomic analysis of the Pseudomonas syringae pv. tomato DC3000 genome. Mol. Microbiol. 45:12071218

\section{AUTHOR-RECOMMENDED INTERNET RESOURCES}

The BioInfoBank Meta server: bioinfo.pl/Meta

Center for Biological Sequence Analysis (CBS) LipoP server: www.cbs.dtu.dk/services/LipoP

National Center for Biotechnology Information (NCBI) LipoP webpage: www.ncbi.nlm.nih.gov/entrez/query.fcgi?cmd=Retrieve $\& d b=$ pubmed $\&$ dopt $=$ Abstract\&list_uids $=12876315 \&$ itool $=$ iconabstr

Protein Data Bank (PDB) database: pdbbeta.rcsb.org/pdb/explore.do?structure $\mathrm{Id}=11 \mathrm{lu}$

Pseudomonas-Plant Interaction website: pseudomonas-syringae.org 